\title{
Why Did So Many People Make So Many Ex Post Bad Decisions? The Causes of the Foreclosure Crisis
}

\section{Citation}

Foote, Christopher L., Kristopher S. Gerardi, and Paul S. Willen. 2012. Why did so many people make so many ex post bad decisions? The causes of the foreclosure crisis. In Rethinking finance: Perspectives on the crisis: April 13, 2012, New York, NY, ed. Alan Blinder, Andrew Lo, and Bob Solow. New York: Russell Sage Foundation.

\section{Published Version}

doi:10.3386/w18082

\section{Permanent link}

http://nrs.harvard.edu/urn-3:HUL.InstRepos:10885504

\section{Terms of Use}

This article was downloaded from Harvard University's DASH repository, and is made available under the terms and conditions applicable to Open Access Policy Articles, as set forth at http:// nrs.harvard.edu/urn-3:HUL.InstRepos:dash.current.terms-of-use\#OAP

\section{Share Your Story}

The Harvard community has made this article openly available.

Please share how this access benefits you. Submit a story.

Accessibility 
NBER WORKING PAPER SERIES

\title{
WHY DID SO MANY PEOPLE MAKE SO MANY EX POST BAD DECISIONS? THE CAUSES OF THE FORECLOSURE CRISIS
}

\author{
Christopher L. Foote \\ Kristopher S. Gerardi \\ Paul S. Willen \\ Working Paper 18082 \\ http://www.nber.org/papers/w18082 \\ NATIONAL BUREAU OF ECONOMIC RESEARCH
1050 Massachusetts Avenue
Cambridge, MA 02138
}

May 2012

This paper was prepared for the conference, "Rethinking Finance: New Perspectives on the Crisis," organized by Alan Blinder, Andy Lo and Robert Solow and sponsored by the Russell Sage and Century Foundations. Thanks to Alberto Bisin, Ryan Bubb, Scott Frame, Jeff Fuhrer, Andreas Fuster, Anil Kashyap, Andreas Lehnert, and Bob Triest for helpful discussions and comments. The opinions expressed herein are those of the authors and do not represent the official positions of the Federal Reserve Banks of Boston or Atlanta, the Federal Reserve System, or the National Bureau of Economic Research.

NBER working papers are circulated for discussion and comment purposes. They have not been peerreviewed or been subject to the review by the NBER Board of Directors that accompanies official NBER publications.

(C) 2012 by Christopher L. Foote, Kristopher S. Gerardi, and Paul S. Willen. All rights reserved. Short sections of text, not to exceed two paragraphs, may be quoted without explicit permission provided that full credit, including $\odot$ notice, is given to the source. 
Why Did So Many People Make So Many Ex Post Bad Decisions? The Causes of the Foreclosure Crisis

Christopher L. Foote, Kristopher S. Gerardi, and Paul S. Willen

NBER Working Paper No. 18082

May 2012

JEL No. D14,D18,D53,D82,G01,G02,G38

\begin{abstract}
We present 12 facts about the mortgage crisis. We argue that the facts refute the popular story that the crisis resulted from finance industry insiders deceiving uninformed mortgage borrowers and investors. Instead, we argue that borrowers and investors made decisions that were rational and logical given their ex post overly optimistic beliefs about house prices. We then show that neither institutional features of the mortgage market nor financial innovations are any more likely to explain those distorted beliefs than they are to explain the Dutch tulip bubble 400 years ago. Economists should acknowledge the limits of our understanding of asset price bubbles and design policies accordingly.
\end{abstract}

Christopher L. Foote

Federal Reserve Bank of Boston

Research Department, T-8

600 Atlantic Avenue

Boston, MA 02210

chris.foote@bos.frb.org

Kristopher S. Gerardi

Federal Reserve Bank of Atlanta

1000 Peachtree St. NE

Atlanta, GA 30309

kristopher.gerardi@atl.frb.org
Paul S. Willen

Federal Reserve Bank of Boston

600 Atlantic Avenue

Boston, MA 02210-2204

and NBER

willen968@gmail.com 


\section{Introduction}

More than four years after defaults and foreclosures began to rise, economists are still debating the ultimate origins of the U.S. mortgage crisis. Losses on residential real estate touched off the largest financial crisis in decades. Why did so many people -including homebuyers and the purchasers of mortgage-backed securities - make so many decisions that turned out to be disastrous ex post?

The dominant explanation claims that well-informed mortgage insiders used the securitization process to take advantage of uninformed outsiders. The typical narrative follows a loan from a mortgage broker through a series of Wall Street intermediaries to an ultimate investor. According to this story, depicted graphically in the top panel of Figure 1, deceit starts with a mortgage broker, who convinces a borrower to take out a mortgage that initally appears affordable. Unbeknownst to the borrower, the interest rate on the mortgage will reset to a higher level after a few years, and the higher monthly payment will force the borrower into default.

The broker knows that the mortgage is hard wired to explode but does not care, because the securitization process means that he will be passing this mortgage on to someone else. Specifically, an investment banker buys the loan for inclusion in a mortgage-backed security. In constructing this instrument, the banker intentionally uses newfangled, excessively complex financial engineering so that the investor cannot figure out the problematic nature of the loan. The investment banker knows that the investor is likely to lose money but he does not care, because it is not his money. When the loan explodes, the borrower loses his home and the investor loses his money. But the intermediaries who collected substantial fees to set up the deal have no "skin in the game" and therefore suffer no losses.

This insider/outsider interpretation of the crisis motivated an Academy Award-winning documentary, appropriately titled Inside Job. It has also motivated policies designed to prevent a future crisis, including requirements that mortgage lenders retain some skin in the game for certain mortgages in the future.

In this paper, we lay out 12 facts about the mortgage market during the boom years and argue that they refute much of the insider/outsider explanation of the crisis. Borrowers did get adjustable-rate mortgages but the resets of those mortgages did not cause the wave of defaults that started the crisis in 2007. Indeed, to a first approximation, "exploding" mortgages played no role in the crisis at all. Arguments that deceit by investment bankers sparked the crisis are also hard to support. Compared to most investments, mortgagebacked securities were highly transparent and their issuers willingly provided a great deal of information to potential purchasers. These purchasers could and did use this information to 
measure the amount of risk in mortgage investments and their analysis was accurate, even ex post. Mortgage intermediaries retained lots of skin in the game. In fact, it was the losses of these intermediaries - not mortgage outsiders - that nearly brought down the financial system in late 2008. The biggest winners of the crisis, including hedge fund managers John Paulson and Michael Burry, had little or no previous experience with mortgage investments until some strikingly good bets on the future of the U.S. housing market earned them billions of dollars.

Why then did borrowers and investors make so many bad decisions? We argue that any story consistent with the 12 facts must have overly optimistic beliefs about house prices at its center. The lower panel of Figure 1 summarizes this view. Rather than drawing a sharp demarcation between insiders and outsiders, it depicts a "bubble fever" infecting both borrowers and lenders. If both groups believe that house prices would continue to rise rapidly for the foreseeable future, then it is not surprising to find borrowers stretching to buy the biggest houses they could and investors lining up to give them the money. Rising house prices generate large capital gains for home purchasers. They also raise the value of the collateral backing mortgages, and thus reduce or eliminate credit losses for lenders. In short, higher house price expectations rationalize the decisions of borrowers, investors, and intermediaries - their embrace of high leverage when purchasing homes or funding mortgage investments, their failure to require rigorous documentation of income or assets before making loans, and their extension of credit to borrowers with histories of not repaying debt. If this alternative theory is true, then securitization was not a cause of the crisis. Rather, securitization merely facilitated transactions that borrowers and investors wanted to undertake anyway.

The bubble theory therefore explains the foreclosure crisis as a consequence of distorted beliefs rather than distorted incentives. A growing literature in economics - inspired in part by the recent financial crisis - is trying to learn precisely how financial market participants form their beliefs and what can happen when these beliefs become distorted. ${ }^{1}$ The idea that distorted beliefs are responsible for the crisis has also received some attention in the popular press. In one analysis of the crisis, New York Times columnist Joe Nocera referenced the famous Dutch tulip bubble of the 1630s to argue that a collective mania about house prices, rather than individual malfeasance on the part of mortgage industry insiders, may be the best explanation for why the foreclosure crisis occurred:

Had there been a Dutch Tulip Inquiry Commission nearly four centuries ago, it

\footnotetext{
${ }^{1}$ Some examples of this work include Gennaioli and Shleifer (2010), Gennaioli, Shleifer, and Vishny (2011 [online proof]), Barberis (2011), Brunnermeier, Simsek, and Xiong (2012), Simsek (2012), Fuster, Laibson, and Mendel (2010), Geanakoplos (2009), and Burnside, Eichenbaum, and Rebelo (2011).
} 
would no doubt have found tulip salesmen who fraudulently persuaded people to borrow money they could never pay back to buy tulips. It would have criticized the regulators who looked the other way at the sleazy practices of tulip growers. It would have found speculators trying to corner the tulip market. But centuries later, we all understand that the roots of tulipmania were less the actions of particular Dutchmen than the fact that the entire society was suffering under the delusion that tulip prices could only go up. That's what bubbles are: they're examples of mass delusions.

Was it really any different this time? In truth, it wasn't. To have so many people acting so foolishly required the same kind of delusion, only this time around, it was about housing prices (Nocera 2011).

In both popular accounts and some academic studies, the inside job explanation and the bubble theory are often commingled. Analysts often write that misaligned incentives in the mortgage industry (a key part of the inside job explanation) contributed to an expansion of mortgage credit that sent house prices higher (a key part of the bubble explanation). We believe that the two explanations are conceptually distinct, and that the bubble story is a far better explanation of what actually happened. To put this another way, according to the conventional narrative, the bubble was a by-product of misaligned incentives and financial innovation. As we argue in Section 3, neither the facts nor economic theory draw an obvious causal link from underwriting and financial innovation to bubbles.

No one doubts that the availability of mortgage credit expanded during the housing boom. In particular, no one doubts that many borrowers received mortgages for which they would have never qualified before. The only question is why the credit expansion took place. Economists and policy analysts have blamed a number of potential culprits for the credit expansion, but we will show that the facts exonerate the usual suspects. As noted above, some analysts claim that the credit expansion occurred because of improper incentives inherent in the so-called originate-to-distribute model of mortgage lending. Yet mortgage market participants had been buying and selling U.S. mortgages for more than a century without much trouble. In a similar vein, some authors blame the credit expansion on the emergence of nontraditional mortgages, like option ARMs and reduced documentation loans, but these products had been around for many years before the housing boom occurred. Other writers blame the credit expansion on the federal government, which allegedly pushed a too-lax lending model on the mortgage industry. But government involvement in mortgage lending had been massive throughout the postwar era without significant problems. In contrast to these these explanations for the credit expansion, the facts suggest that the expansion occurred simply because people believed that housing prices would keep going up - the defining char- 
acteristic of an asset bubble. Bubbles do not need securitization, government involvement, or nontraditional lending products to get started. Bubbles in many other assets have occurred without any of these things - not only tulips in seventeenth-century Holland, but also shares of the South Sea Company in eighteenth-century England, U.S. equities and Florida land in the 1920s, even Beanie Babies and technology stocks in the 1990s. ${ }^{2}$ As the housing bubble inflated it encouraged lenders to extend credit to borrowers who had been constrained in the past, since higher house prices would ensure repayment of the loans. Much of this credit was channeled to subprime borrowers by securitized credit markets, but this does not mean that securitization "caused" the crisis. Instead, expectations of higher house prices made investors more willing to use both securitized markets and nontraditional mortgage products - because those markets and products delivered the biggest profits to investors as housing prices rose.

Another reason to keep the two explanations distinct is that they suggest very different agendas for real-world regulators and academic economists. If the inside job story is true, then prevention of a future crisis requires regulations to ensure that intermediaries inform borrowers and investors of relevant facts and that incentives in the securitization process are properly aligned. But if the problem was some collective self-fulfilling mania, then such regulations will not work. If house prices are widely expected to rise rapidly, then warning borrowers that their future payments will rise will have no effect on their decisions. Similarly, intermediaries will be only too willing to keep some skin in the game if they expect rising prices to eliminate credit losses. For economists, the bubble theory implies that research should focus on a more general attempt to understand how beliefs are formed about the prices of long-lived assets. Gaining this understanding is an enormous challenge for the economics profession. From tulips to tech stocks, outbreaks of optimism have appeared repeatedly, but no robust theory has emerged to explain these episodes. As a telling example, at the peak of the housing boom economic theory could not provide academic researchers with clear predictions of where prices were going or if they were poised to fall. Scientific ignorance about what causes asset bubbles implies that policymakers should focus on making the housing finance system as robust as possible to significant price volatility, rather than trying to correct potentially misaligned incentives.

The multitude of questions suggested by the financial crisis could never be answered by one single theory - or in one single paper. For example, as we discuss below, the top-rated tranches of Wall Street's mortgage-backed securities performed much better than the toprated tranches of its collateralized debt obligations, another type of structured security. This

\footnotetext{
${ }^{2}$ The classic reference on tulipmania is MacKay (2003 [1841]). A contrarian view on tulipmania is found in Garber (2000), which reviews data on tulip prices and argues that they can be justified by fundamentals during this period. The book takes a similar stance on other early bubbles, including the South Sea Bubble (1720) and the Mississippi Bubble (1719-1720).
} 
discrepancy occurred even though both types of securities were ultimately collateralized by subprime mortgages, and even though both types of securities were constructed by the same investment banks. We do not believe that securitization alone caused the crisis but, by

channeling money from investors to borrowers with ruthless efficiency, it may have allowed speculation on a scale that would have been impossible to sustain with a less sophisticated financial system. As economists, we believe that the ultimate answers to questions like these will involve information and incentives. But we also believe that that an examination of the facts that we present about the mortgage market do rule out the most common informationand-incentives story invoked to explain the crisis - that poor incentives caused mortgage industry insiders to take advantage of misinformed outsiders.

The paper is organized as follows. Section 2 lays out the 12 facts about the U.S. mortgage market that are critical in rationalizing borrower and lender decisions. Section 3 relates these facts to various economic theories about the crisis, and Section 4 concludes with some implications for policy makers.

\section{Twelve Facts About the Mortgage Market}

\section{Fact 1: Resets of adjustable-rate mortgages did not cause the foreclosure crisis}

One theory for why borrowers took out loans they could not repay is that their lenders misled them by granting them loans that initially appeared affordable but became unaffordable later on. In particular, analysts have pointed to the large number of adjustable-rate mortgages (ARMs) originated in the years immediately preceding the crisis, attributing the rise in delinquencies and foreclosures to the "payment shocks" associated with ARM-rate adjustments. Borrowers, they argued, had either not realized that their payments would rise or had been assured that they could refinance to lower-rate mortgages when the resets occurred.

The "exploding ARM" theory has played a central role in narratives about the crisis since 2007, when problems with subprime mortgages first gained national attention. In April 2007, Sheila Bair, then the chair of the Federal Deposit Insurance Corporation, testified to Congress that " ' $[\mathrm{m}]$ any subprime borrowers could avoid foreclosure if they were offered more traditional products such as 30-year fixed-rate mortgages" " (Bair 2007).

Yet the data are not kind to the exploding ARM theory. Figure 2 shows the path of interest rates and defaults for three vintages of the most problematic type of ARM, socalled subprime $2 / 28$ s. These mortgages had fixed interest rates for the first two years, then 
adjusted to "fully indexed" rates every six months for the loan's 28 remaining years. ${ }^{3}$ The figure shows that, at least for subprime $2 / 28$ s, payment shocks did not lead to defaults. The top left panel depicts interest rates and cumulative defaults for subprime $2 / 28$ s originated in January 2005. For these mortgages, the initial interest rate was 7.5 percent for the first two years. Two years later, in January 2007, the interest rate rose to 11.4 percent, resulting in a payment shock of 4 percentage points, or more than 50 percent in relative terms. However, the lower part of the panel shows that delinquencies for the January 2005 loans did not tick up when this reset occurred. In fact, the delinquency plot shows no significant problems for the 2005 borrowers two years into their mortgages when their resets occurred. The top right panel displays data for $2 / 28$ s originated in January 2006. These loans had initial rates of 8.5 percent that reset to 9.9 percent in January 2008. This increase of 1.4 percentage points results in a relative increase of about 16 percent, one-third the size of the payment shock for the previous vintage. Yet even though the payment shock for the January 2006 loans was smaller than that for the 2005 loans, their delinquency rate was higher. Finally, the worst-performing loans, those originated in January 2007, are depicted in the figure's bottom panel. When these loans reset in January 2009, their fully indexed rates were actually lower than their initial rates. However, the contract on the typical 2/28 mortgage specified that the interest rate could never go below the initial rate, so for all practical purposes subprime 2/28s from January 2007 were fixed-rate loans. But as the lower part of the panel indicates, these "fixed-rate" loans had the highest delinquency rates of any vintage shown in the figure.

As many have pointed out, subprime $2 / 28$ s were not the only loans with payment shocks. In 2004 and 2005, lenders originated many nontraditional, or "exotic," mortgages, which often had larger payment shocks and which we discuss in more detail below. Table 1 attempts to quantify the impact of payment shocks across the entire mortgage market by looking at all foreclosures from 2007 through 2010, regardless of the type of mortgage. The goal is to determine whether the monthly payments faced by borrowers when they first became delinquent were higher than the initial monthly payments on their loans. The top panel of this table shows that this is true for only 12 percent of borrowers who eventually lost their homes to foreclosure. The overwhelming majority of foreclosed borrowers - 84 percent - were making the same payment at the time they first defaulted as when they originated their loans. A main reason for this high percentage is that fixed-rate mortgages (FRMs) account for 59 percent of the foreclosures between 2007 and 2010.

Table 1 puts an upper bound on the role that deceptively low mortgage payments may have played in causing the crisis. Basically, it tells us that if we had replaced all of the complex

\footnotetext{
${ }^{3}$ Typically, the fully indexed rate was a fixed amount over some short-term rate, for example 6 percentage points above the six-month LIBOR.
} 
mortgage products with fixed-rate mortgages, we would have prevented at most 12 percent of the foreclosures during this time period. But even 12 percent is a substantial overestimate, because the table shows that fixed-rate borrowers also lost their homes to foreclosure as well.

While FRMs accounted for most defaults, this does not mean that FRMs suffered higher default rates. In fact, fixed-rate loans defaulted less often than adjustable-rate loans; the predominance of fixed-rate loans among defaulted mortgages stems from the fact that FRMs are more common than ARMs. Yet we should not overstate the better performance of fixedrate loans, particularly among subprime borrowers. The bottom panel of Table 1 shows that 53 percent of subprime ARMs originated between 2005 and 2007 have experienced at least one 90-day delinquency. The corresponding figure for FRMs is 48 percent, a difference of only 5 percentage points. ${ }^{4}$ Even this small difference does not indicate that subprime ARMs were worse products than FRMs. The lack of any relationship between the timing of the initial delinquency and the timing of the reset has led most researchers to conclude that ARMs performed worse than FRMs because they attracted less creditworthy borrowers, not because of something inherent in the ARM contract itself. Even if we did believe that the ARM-versus-FRM performance difference was a causal effect and not a selection effect, almost half of borrowers with subprime FRMs became seriously delinquent. The terrible performance of subprime FRMs contradicts the claim of Martin Eakes, the head of the Center for Responsible Lending, that "exploding ARMs are the single most important factor causing financial crisis for millions" (Eakes 2007).

\section{Fact 2: No mortgage was "designed to fail"}

Some critics of the lending process have argued that the very existence of some types of mortgages is prima facie evidence that borrowers were misled. These critics maintain that reduced-documentation loans, loans to borrowers with poor credit histories, loans with no downpayments, and option ARMs were all "designed to fail," so no reasonable borrower would willingly enter into such transactions. ${ }^{5}$ In fact, the large majority of these loans succeeded for both borrower and lender alike.

In Figure 3, we graph failure rates for four categories of securitized nonprime loans. Along the horizontal axis are years of origination, and the figure defines failure as being at least

\footnotetext{
${ }^{4}$ To some extent, this 5 percent difference understates the performance differential among subprime ARMs and FRMs because originations of subprime FRMs were concentrated in the later vintages of loans which had the highest default rates. We comment on this concentration below. Also, a performance gap between subprime FRMs and ARMs is robust to a more sophisticated analysis that controls for observable characteristics (Foote et al. 2008).

${ }^{5}$ The phrase "designed to fail" appears in speeches by presidential candidate Hillary Clinton, Senator Charles Schumer of New York, and press releases from prominent attorneys general including Martha Coakley of Massachusetts and Catherine Cortez Masto of Nevada.
} 
60 days delinquent two years after the loan was originated. ${ }^{6}$ The figure shows that the vast majority of loans originated from 2000 through 2005 were successful. For example, the lower left panel shows that in 2007, after the housing market had begun to sour, only 10 percent of the borrowers who took out low- or no-documentation mortgages in 2005 were having serious problems. Additionally, loans requiring no downpayments (top right panel) and even "risklayered" loans (bottom right panel) originated before 2006 also display failure rates that are well under 10 percent. Loans in the upper left panel were made to borrowers with credit scores below 620, who typically had a history of serious debt repayment problems. Yet after two years, more than 80 percent of low-scoring borrowers who originated loans before 2006 had either avoided seriously delinquency or had repaid their loans. Given their spotty credit histories, the performance of these borrowers indicates remarkable success, not failure.

Some might argue that the loans in Figure 3 succeeded only because the borrowers were able to refinance or sell. But it would be wrong to classify prepayments as failures. In many cases, the simple fact of making 12 consecutive monthly payments allowed the borrower to qualify for a lower-cost loan. In such cases, the refinance is a success for the borrower, who gets a loan with better terms, as well as the lender, who is fully repaid.

In the end, the idea that subprime or Alt-A loans were designed to fail does not fit the facts. This finding should not be surprising. Marketing products that do not work is usually a bad business plan, even in the short run, whether one is producing mortgages or motorcycles. The fact that failure rates for all the loans in Figure 3 rose at about the same time suggests that these mortgages were not designed to fail. Instead, they were not designed to withstand the stunning nationwide fall in house prices that began in 2006. We will return to this theme later.

\section{Fact 3: There was little innovation in mortgage markets in the 2000s}

Another popular claim is that the housing boom saw intense innovation in mortgage markets. According to the conventional wisdom, lenders began to offer types of mortgages that they never had before, including loans with no downpayments, loans with balances that increased over time, ${ }^{7}$ and loans that lacked rigorous documentation of borrower income and assets. In more nuanced versions of the story, lenders did not innovate so much as expand the market for nontraditional mortgages. As Allen Fishbein of the Consumer Federation of America described these nontraditional mortgages in Congressional testimony:

Traditionally, these types of loans were niche products that were offered to upscale

\footnotetext{
${ }^{6}$ Our choice of the two-year period does not influence our results. Figure 2 shows that default rates on subprime loans did not spike after two years.

${ }^{7}$ The balances of a traditional "amortizing" mortgage decreases over time, because the borrower pays both interest and part of the outstanding principal each month.
} 
borrowers with particular cash flow needs or to those expecting to remain in their homes for a short time (Fishbein 2006).

Figure 3 shows that originations of riskier loans increased dramatically from 2002 to 2006 and commentators point to such data as evidence of large-scale innovation.

The historical record paints a different picture. It is approximately true to say that prior to 1981, virtually all mortgages were either fixed-rate loans or something close to it. ${ }^{8}$ Yet the emergence of nontraditional mortgages still predates the 2000s mortgage boom by many years. Perhaps the most extreme form of nontraditional mortgage is the "payment-option ARM," which allows a borrower to pay less than the interest due on the loan in a given month. The difference is made up by adding the arrears to the outstanding mortgage balance. This type of loan was invented in 1980 and approved for widespread use by the Federal Home Loan Bank Board and the Office of the Comptroller of the Currency in 1981 (Harrigan 1981; Gerth 1981). Large California thrifts subsequently embraced the option ARM, which would eventually play a central role in the Golden State's housing market (Guttentag 1984). By 1996, one-third of all originations in California were option ARMs (Stahl 1996); we reproduce a 1998 advertisement for this product in the left panel of Figure 4. The large volume of option ARMs belies the claim that this instrument was a niche product. Indeed, the lender most closely associated with option ARMs, Golden West, made a point of avoiding "upscale" borrowers. Despite originating almost two-thirds of its loans in California, the typical Golden West mortgage in 2005 was for less than $\$ 400,000$ (Savastano 2005).

Some confusion about the growth of option ARMs results from the fact that they were almost exclusively held in bank portfolios until 2004. The loan was an attractive portfolio addition because it generated floating-rate interest income and thus eliminated the lender's interest-rate risk. At the same time, the option ARM's flexible treatment of amortization smoothed out payment fluctuations for the borrower. In any event, even though option ARMs were available in the 1980s and 1990s, they do not show up in datasets of securitized loans until 2004. ${ }^{9}$ Even then, the majority of securitized option ARMs were made in the markets where they were already common as portfolio loans (Liu 2005).

Another type of nontraditional mortgage, the reduced-documentation loan, also began to spread in the 1980s; the right panel of Figure 4 shows a 1989 ad for such a loan. By 1990, Fannie Mae reported that between 30 and 35 percent of the loans it insured were low- and no-doc loans (Sichelman 1990). Ironically, commentators raised virtually identical concerns about low-doc lending in the early 1990s as they did in 2005. For example, Lew Sichelman, a

\footnotetext{
${ }^{8}$ One author's father took out an interest-only adjustable-rate, balloon payment mortgage in 1967 but that was an exceptional situation.

${ }^{9}$ See, for example, Table 4 of Dokko et al. (2009).
} 
veteran mortgage industry journalist, wrote in 1990 that "in recent years, lenders, spurred by competitive pressures and secure in the knowledge that they could peddle questionable loans to unsuspecting investors on the secondary market, have been approving low- and no-doc loans with as little as 10 percent down" (Sichelman 1990).

\section{Fact 4: Government policy toward the mortgage market did not change much from 1990 to 2005}

While the conventional wisdom blames the foreclosure crisis on too little government regulation of the mortgage market, an influential minority believes that government interventions went too far. ${ }^{10}$ According to this view, policymakers in the 1990s hoped to expand homeownership, either for its own sake or as a way to combat the effects of rising income inequality. Consequently, this narrative contends that policymakers allowed lenders to abandon traditional and prudent underwriting guidelines that had worked well for decades. In reality, government officials talked at length about lending and homeownership in the 1990s and early 2000s, but actual market interventions were modest. In fact, compared to the massive federal interventions in the U.S. mortgage market during the immediate postwar era, government interventions during the recent housing boom were virtually nonexistent.

For a concrete example, consider the size of required downpayments. Morgenson and Rosner (2011) write that because of the Clinton Administration's emphasis on homeownership:

[I]n just a few short years, all of the venerable rules governing the relationship between borrower and lender went out the window, starting with the elimination of the requirements that a borrower put down a substantial amount of cash in a property (Morgenson and Rosner 2011, p. 3). ${ }^{11}$

It is true that large downpayments were once required to purchase homes in the United States. It is also true that the federal government was instrumental in reducing required downpayments in an effort to expand homeownership. The problem for the bad government theory is that the timing of government involvement is almost exactly 50 years off. The key event was the Servicemen's Readjustment Act of 1944, better known as the GI Bill, in which the federal government promised to take a first-loss position equal to 50 percent of the mortgage balance, up to $\$ 2,000$, on mortgages originated to returning veterans. The limits on the Veteran's Administration (VA) loans were subsequently and repeatedly raised, while similar guarantees were later added to loans originated through the Federal Housing Administration (FHA). The top panel of Figure 5 graphs average loan-to-value (LTV) ratios

\footnotetext{
${ }^{10}$ See Morgenson and Rosner (2011) and Rajan (2010) for two leading examples of the genre.

${ }^{11}$ This quotation goes on to claim that requirements to verify income and demonstrate repayment ability were also reduced.
} 
for various types of loans, including those with FHA and VA insurance. It shows that borrowers took advantage of these government programs to buy houses with little or no money down. By the late 1960s, the average downpayment on a VA loan was around 2 percent. A large fraction of borrowers put down nothing at all. Government involvement in the early postwar mortgage market was broad; in no sense were FHA and VA mortgages "niche products." The bottom panel of Figure 5 shows that together, the FHA and the VA accounted for almost half of originations in the 1950s before tailing off somewhat in the 1960s.

In contrast to the heavy government involvement in housing during the immediate postwar era, recent data on LTV ratios suggests no major federal mortgage market interventions in the 1990s and 2000s. Figure 6 shows combined LTV ratios for purchase mortgages in Massachusetts from 1990 to 2010, the period when government intervention is supposed to have caused so much trouble. ${ }^{12}$ To be sure, the boom years of 2002-2006 saw an increase in zero-down financing. But the data also show that even before the boom, most borrowers got loans without needing to post a 20 percent downpayment. ${ }^{13}$ In particular, Morgenson and Rosner (2011) point to the Clinton administration's National Partners in Homeownership initiative in 1994 as the starting point for an ill-fated credit expansion that led to the crisis. But inspection of Figure 6 does not support the assertion that underwriting behavior was significantly changed by that program. The distribution of downpayments is remarkably stable after 1994. The share of zero-down loans actually falls. ${ }^{14}$

All told, it is impossible to find any government housing market initiative in recent years that is remotely comparable to the scope of the GI Bill and FHA's subsequent expansion. It is important to stress that the FHA and the VA were widely understood to encourage high-risk lending to less-qualified borrowers. The delinquency rates on the loans they guaranteed were several times higher than delinquency rates on conventional loans. But the two government programs were also considered successful because they enabled lower-income Americans to own their own homes. ${ }^{15}$

\section{Fact 5: The originate-to-distribute model was not new}

One of the most important motivating principles of the Dodd-Frank Act, passed in 2010 to reduce the chance of future financial crises, was that the originate-to-distribute (OTD) model of lending shouldered much of the blame for the foreclosure crisis. Congressman Barney

\footnotetext{
${ }^{12}$ Combined LTV ratios, sometimes denoted CLTV ratios, include all mortgages taken out by the homeowner at the time of purchase, including so-called piggyback mortgages.

${ }^{13}$ Public records do not allow us to know whether a purchase corresponds to a first-time homebuyer. If it were possible to focus on those purchases alone, the average downpayment would undoubtedly be even lower than the average that includes all purchases.

${ }^{14}$ Glaeser, Gottlieb, and Gyourko (2010) look at data for a broader set of cities and finds similar results.

${ }^{15}$ See Herzog and Earley (1970) for a contemporary analysis of default rates on FHA, VA, and conventional mortgages.
} 
Frank, then the chairman of the House Financial Services Committee, put it this way: " 'If I can make a whole bunch of loans and sell the entire right to collect those to somebody else, at that point I don't care...whether or not they pay off. We have to prohibit that.' "16 The Dodd-Frank Act requires mortgage originators to retain a slice of the credit risk of the mortgages they generate unless the credit quality of the mortgages is strong enough to earn an exemption.

Yet the OTD model was central to the U.S. mortgage market for decades before the financial crisis began. In the immediate postwar era, an important manifestation of the OTD model was the mortgage company. These firms borrowed money from banks in order to fund mortgages for sale to outside investors, who often held the mortgages as whole loans. These lenders also "serviced" the loans on behalf of the investors and received a fixed percentage of the loan balance every month as compensation. A 1959 National Bureau of Economic Research study of mortgage companies lists the fundamental features of the OTD model that would be familiar to modern originators as well:

The modern mortgage company is typically a closely held, private corporation whose principal activity is originating and servicing residential mortgage loans for institutional investors. It is subject to a minimum degree of federal or state supervision, has a comparatively small capital investment relative to its volume of business, and relies largely on commercial bank credit to finance its operations and mortgage inventory. Such inventory is usually held only for a short interim between closing mortgage loans and their delivery to ultimate investors (Klaman 1959, p. 239).

The importance of mortgage companies grew in the second half of the twentieth century. The top left panel of Figure 7 shows that the market share of mortgage companies was around 20 percent in the 1970s and reached nearly 60 percent by 1995 .

A focus on mortgage companies alone understates the role of the OTD model, however. Starting in the 1970s, the OTD model was adopted by other financial institutions, most importantly savings and loans (S\&Ls), which financed the majority of U.S. residential lending in the postwar period. S\&L's had historically followed an originate-and-hold model. By the late 1970s, however, rising interest rates had generated a catastrophic mismatch between the low interest rates that S\&Ls received on their existing mortgages and their current costs of funds. This mismatch, which would eventually render more than half of S\&Ls insolvent, encouraged thrifts either to turn to adjustable-rate mortgages or to sell the mortgages they originated to the secondary market. The top right panel of Figure 7 shows that by the

\footnotetext{
${ }^{16}$ Congressman Frank is quoted in Arnold (2009).
} 
late 1980s, S\&Ls sold almost as many loans as they originated. In other words, most had adopted the OTD model and had become, for all practical purposes, mortgage companies. The bottom panel of Figure 7 shows that the decline of the originate-to-hold model was well underway 30 years before the boom of the 2000s.

Over time, the OTD model evolved. In the 1950s, mortgage companies typically sold their loans to insurance companies, which kept them on portfolio as whole loans. Starting in the 1970s, this framework gave way to mortgage-backed securities (MBS), which were largely guaranteed by Ginnie Mae. The other government-sponsored housing agencies, Fannie Mae and Freddie Mac, became dominant players in the early 1980s. This period also saw the emergence of the private-label securities market, and in the 2000s, the private-label market grew at the expense of the agency market. However, the institutional framework of the OTD model remained more or less identical to what it was in the 1950s. Lenders originated loans and sold them to other institutions. Typically the loans were then serviced by the originating lender, but other servicing arrangements were also possible. ${ }^{17}$

\section{Fact 6: MBSs, CDOs, and other "complex financial products" had been widely used for decades}

Another source of potential confusion lies in the distinction between the OTD model and securitization. Securitization implies originate-to-distribute, but the OTD model existed for decades before securitization emerged. As noted above, early manifestations of the OTD model generally featured the sale of whole loans into investor portfolios. Only in the 1970s and 1980s did Ginnie Mae, Fannie Mae and Freddie Mac began to arrange and/or insure pass-through securities, whereby investors could buy a pro-rated share of a pool of mortgages. Private-label securities were also being developed at that time, but the emergence of these securities proceeded in fits and starts. In 1977, Salomon Brothers arranged the first privatelabel MBS deal, which was considered something of a failure. ${ }^{18}$ Among other problems, existing state laws prevented most of the relevant investors from buying the bonds. Issuing securities through Fannie Mae and Freddie Mac allowed issuers to address these laws, and the collateralized mortgage obligation (CMO) emerged in the early 1980s as a way to sell an

\footnotetext{
${ }^{17}$ When recounting the history of the OTD model, it is important to distinguish between mortgage brokers and mortgage bankers. Jiang, Nelson, and Vytlacil (2011) claim that brokers "issue[d] loans on the bank's behalf for commissions but do not bear the long-term consequences of low-quality loans," but this statement is incorrect. Brokers, who often have specific knowledge of a local market, can help match borrowers with lenders, but they do not underwrite or fund mortgages. Rather, mortgage banks, which include mortgage companies and S\&L's, underwrite and fund loans. These lenders can choose to place a brokered loan in a security, sell it to another lender, or keep it on portfolio. In short, there is no necessary connection between brokers and the OTD model; the decision to extend a loan rests entirely with the lender, because the lender comes up with the money.

${ }^{18}$ See Ranieri (1996) for a discussion.
} 
array of complex securities with different repayment properties (principal-only, interest-only, floating-rate notes, fixed-rate notes, and so on) secured by a pool of mortgages. Until the 1986 Tax Reform Act, it remained difficult to construct a complex mortgage deal without Fannie Mae or Freddie Mac's involvement. But that Act created a financial structure called a Real Estate Mortgage Investment Conduit (REMIC), which allowed issuers to create complex MBSs without the assistance of one of the GSEs.

The emergence of collateralized debt obligations (CDOs) was the next step in the securitization of debt. The CDO was invented in the early 1990s as a way for banks to sell the risk on pools of commercial loans (Tett 2009). Over time, financial institutions realized that the CDO structure could also be used for pools of risky tranches from securities, including private-label securities backed by mortgages. In 2000, investment banks began to combine the lower-rated tranches of mortgage securities, typically subprime asset-backed securities (ABS), with other forms of securitized debt to create CDOs. The ABS CDO was born. ${ }^{19}$ As Cordell, Huang, and Williams (2011) shows, the poor performance of ABS CDOs in the early 2000s was widely blamed on the presence of nonmortgage assets like tranches from car-loan or credit-card deals, so the ABS CDO deals became dominated by tranches from subprime ABS. Consequently, as the housing market boomed in the mid-2000s, ABS CDOs became increasingly pure plays on the subprime mortgage market.

Looking back, a remarkable feature about the boom in securitized lending in the mid2000 s is that the institutional and legal framework it required had been in place since at least the early 1990s, and for some key components much earlier than that. In other words, what is significant about the evolution of the mortgage market in the 2000s is how little institutional change took place. As far as the mortgage and mortgage-securities markets were concerned, there were few legal or institutional changes, and certainly no major ones in the period immediately preceding the lending boom. It is true that there was dramatic growth in the use of subprime ABS to fund loans, as well as the use of ABS CDOs to fund the lower-rated tranches of subprime deals. But this growth did not occur because lenders and investors had been unable to use those structures earlier. In short, the idea that the boom in securitization was some exogenous event that sparked the housing boom receives no support from the institutional history of the American mortgage market.

\section{Fact 7: Mortgage investors had lots of information}

One of the pillars of the inside job theory of the mortgage crisis is that mortgage industry

\footnotetext{
${ }^{19}$ In the industry, bonds backed by subprime loans were considered asset-backed securities (ABS) rather than MBS, because subprime lending began as an alternative to unsecured credit for troubled borrowers. Thus, as an institutional matter, subprime lending was part of the consumer lending, or ABS market, not the mortgage, or MBS market.
} 
insiders were stingy with information about the securities they structured and sold. In fact, issuers supplied a great deal of information to potential investors. Simply put, the market for mortgage investments was awash in information.

To start with, prospectuses for pools of loans provided detailed information on the underlying loans at the time they were originated. This information included the distributions of the key credit-quality variables, such LTV ratios, documentation status, and borrower credit scores. More importantly, they provided conditional distributions showing, for example, the share of borrowers with FICO scores between 600 and 619 or the share of borrowers with LTV ratios between 95 and 99 percent. In many cases, issuers provided loan-level details in what was known as a "free writing prospectus."

To nonexperts, one of the most confusing things about the mortgage securities market is that issuers were quite careful to document the extent to which they did not document a borrower's income and assets. Loans were typically given a four-letter code that informed investors whether the information about income $(I)$ and assets $(A)$ were either verified $(V)$, stated $(S)$, or not collected at all $(N)$. For example, the code SIVA meant stated incomeverified assets. ${ }^{20}$ The crucial point here is that investors knowingly bought low-doc/no-doc loans. In fact, we now know that lenders provided loans to borrowers with damaged credit without documenting their incomes not because of any after-the-fact forensic investigation, but rather because lenders broadcasted this information to prospective investors. The origination data in Figure 3, which show the dramatic growth of loans to borrowers with low credit scores and less-than-full income and asset verification, come from data provided to investors - data that were known about and widely commented upon in real time.

The information flow continued after the deals were sold to investors. All issuers provided monthly loan-level information on the characteristics of every loan in the pool, including the monthly payment, the interest rate, the remaining principal balance and the delinquency status of each loan. Issuers also disclosed the disposition of terminated loans, including the dollar amounts of losses that stemmed from short sales or foreclosures. Again, these data were publicly available free of charge, but most investors used a loan-level dataset from the LoanPerformance company, which was a cleaned and standardized version of raw data gathered from many different issuers and lenders.

Investors had access not only to important data, but also to tools that allowed them to use these data to price securities. The MBS and CDOs that contained the mortgages (or the mortgage risk) appeared complex on the surface, but they were in fact straightforward

\footnotetext{
${ }^{20}$ The NINA loan is the basis for the apocryphal "NINJA" loan that is often used as an example of excesses in the boom-era mortgage market. NINJA supposedly stood for "no-income, no job, no assets," but no such loan ever existed. Also, the NINA code, which did exist, did not signify a loan to a borrower with no income. Rather, the code signified that the lender had no information about the borrower's income.
} 
to model. Most investors used a program called Intex that coded all of the rules from a prospectus for the allocation of cash flows to different tranches of a deal. To forecast the performance of a deal, an investor would input into Intex a scenario for the performance of the underlying loans. Intex would then deliver cash flows, taking into account all of the complex features of the deal, including so-called overcollateralization accounts and the treatment of interest income earned on loans that were paid off in the middle of a month. Cordell, Huang, and Williams (2011) shows that using Intex, one could accurately measure the losses and value of $\mathrm{ABS}$ CDOs in real time throughout the crisis.

To illustrate the information available to investors on a CDO transaction, Figure 8 shows pages from the offer documents for the notorious Abacus AC-1 CDO. ${ }^{21}$ These documents provide amounts and CUSIPs ${ }^{22}$ for every security in the deal. Armed with those CUSIPs, a potential investor could use LoanPerformance data to obtain the origination information and current delinquency status of every individual loan in each deal. Then, using Intex, the investor could forecast the cash flows for each reference security under different macroeconomic scenarios.

\section{Fact 8: Investors understood the risks}

Using data supplied by issuers and lenders, as well as quantitative tools designed to exploit this information efficiently, investors were able to predict with a fair degree of accuracy how mortgages and related securities would perform under various macroeconomic scenarios. $^{23}$ Table 2, taken from a Lehman Brothers analyst report published in August 2005, shows predicted losses for a pool of subprime loans originated in the second half of 2005 under different assumptions for U.S. house prices (Mago and Shu 2005). The top three house price scenarios, which range from "base" to "aggressive," predict losses of between 1 and 6 percent. Such losses had been typical of previous subprime deals and implied that investments even in lower-rated tranches of subprime deals would be profitable. The report also considers two adverse scenarios for house prices, one labeled "pessimistic" and the other labeled "meltdown." These two scenarios assume near-term annualized growth in house prices of 0 and -5 percent, respectively. For those scenarios, losses are dramatically worse. The pessimistic scenario generates an 11.1 percent loss while the meltdown scenario generates a

\footnotetext{
${ }^{21}$ Abacus was a deal arranged by Goldman Sachs in 2007 that largely amounted to a bet on whether a collection of BBB subprime securities would default. Hedge fund manager John Paulson took a short position in the deal while IKB and ABN Amro took long positions. The SEC brought fraud charges against Goldman Sachs, alleging that they did not properly disclose the fact that Paulson played a role in choosing the specific securities that made up the deal.

${ }^{22}$ A CUSIP is a 9-character code that identifies any North American security, and is used to facilitate the clearing and settlement of financial trades.

${ }^{23}$ The discussion of facts 8 and 9 is based on Gerardi et al. (2008). We direct interested readers to that paper for a more complete discussion of the issues.
} 
17.1 percent loss. The report goes on to point out that while the pessimistic scenario would lead to write-offs of the lowest-rated tranches of subprime deals, the meltdown scenario would lead to massive losses on all but the highest-rated tranches.

Lehman analysts were not alone in understanding the strong relationship between house prices and losses on subprime loans. As Gerardi et al. (2008) show, analysts at other banks reached similar conclusions and were similarly accurate in their forecasts conditional on house price appreciation outcomes. JPMorgan analysts used MSA-level variation in losses on 2003 subprime originations to produce remarkably accurate predictions about losses (Flanagan et al. 2006a). A UBS slide presentation about subprime securities given in fall 2005 was subtitled, "Its (Almost) All About Home Prices" (Zimmerman 2005).

The Lehman analysis, and others like it, are crucial documents for anyone hoping to understand why investors lined up to buy securities backed by subprime loans. First, the analysis shows that investors knew about the significant risk inherent in subprime deals. Expected losses on a typical prime deal were a fraction of 1 percent - even under the worst scenarios prime losses might reach the low single digits. ${ }^{24}$ According to Table 2, losses on a subprime deal could be many times higher. Given a 50 percent recovery rate in foreclosure, the 17.1 percent loss implied in Lehman's meltdown scenario assumes that lenders would foreclose on one-third of the loans in the pool. The analysis underscores investors' knowledge about the sensitivity of subprime loans to adverse movements in housing prices, and it refutes the idea that investors did not or could not determine how risky these loans were.

A second reason that Table 2 is important is that its forecasts proved to be accurate. Despite its foreboding name, the "meltdown" scenario was actually optimistic with respect to the observed fall in housing prices that began in 2006. The current forecast for losses on deals in the ABX 2006-1 index, which largely contains loans originated in the second half of 2005, is about 22 percent (Jozoff et al. 2012). This is consistent with the relationship between losses and house prices implied by the table. The bottom line is that analysts working in real time had little trouble figuring out how much subprime investors would lose if house prices fell.

The next logical question: given how badly these loans were expected to perform if prices fell, why did investors buy them? We turn to this question next.

\section{Fact 9: Investors were optimistic about house prices}

The answer to why investors purchased subprime securities is contained in the third column of the same Lehman analysis cited above, which lists the probabilities that were

\footnotetext{
${ }^{24}$ The prime losses here refer to losses on nonagency ("jumbo") deals, which included mortgages that were too big to be securitized by Fannie Mae or Freddie Mac. For agency MBS consisting of so-called conforming mortgages, credit risk was born not by investors but by the agencies themselves.
} 
assigned to each of the various house price scenarios. It indicates that the adverse price scenarios received very little weight. In particular, the meltdown scenario - the only scenario generating losses that threatened repayment of any AAA-rated tranche - was assigned only a 5 percent probability. The more benign pessimistic scenario received only a 15 percent probability. By contrast, the top two price scenarios, each of which assumes at least 8 percent annual growth in house prices over the next several years, receive probabilities that sum to 30 percent. In other words, the authors of the Lehman report were bullish about subprime investments not because they believed that borrowers had some "moral obligation" to repay mortgages, or because they didn't realize that the lenders had not fully verified borrower incomes. The authors were not concerned about losses because they thought that house prices would continue to rise, and that steady increases in the value of the collateral backing the loans would cover any losses generated by borrowers who would not or could not repay.

Relative to historical experience, even the baseline forecast was optimistic, and the two stronger scenarios were almost euphoric. A widely circulated calculation by Shiller (2005) showed that real house price appreciation over the period from 1890 to 2004 was less than 1 percent per year. A cursory look at the FHFA national price index gives slightly higher real house price appreciation - more than 1 percent - from 1975 to 2000, but still offers nothing to justify 5 percent nominal annual price appreciation, let alone 8 or 11 percent. Further, even sustained periods of elevated price appreciation are rare. ${ }^{25}$

The optimism was not unique to the Lehman report. Table 3, based on reports from analysts at JPMorgan, shows that optimism reigned even in 2006, after house prices had crested and begun to fall. Well into 2007, the analysts were convinced that the decline would prove transitory and that prices would soon resume their upward march.

Industry analysts were not the only ones optimistic about the housing market. Gerardi, Foote, and Willen (2011) show that there was considerable real-time debate among academic economists on whether house prices in the early 2000s were justified by fundamentals or were instead poised to fall. In any case, the contemporary evidence on what investors believed about prices suggests that their widespread optimism encouraged them to purchase subprime securities, despite the well-understood risks involved.

\section{Fact 10: Mortgage market insiders were the biggest losers}

Perhaps the most compelling evidence against the inside job theory of the crisis concerns the distribution of gains and losses among market participants. If insiders took advantage of outsiders, then those most closely associated with the origination and securitization of

\footnotetext{
${ }^{25}$ Authors' calculations using FHFA national price index deflated using deflator for core PCE.
} 
mortgages should have pocketed the most money or at least incurred the smallest losses. Conversely, investors with little connection to the industry should have suffered the most. In fact, the opposite pattern emerges.

First consider the losers. Table 4 displays losses related to the subprime crisis compiled by Bloomberg as of June 2008. Six of the top 10 institutions in this unhappy group (Citigroup, Merrill Lynch, HSBC, Bank of America, Morgan Stanley, and JPMorgan) not only securitized subprime mortgages, they actually owned companies that originated them. Ironically, the list omits Bear Stearns, the one firm most closely associated with the subprime market. Bear Stearns was heavily involved in every aspect of subprime lending, from origination to securitization to servicing. Yet Bear Stearns does not appear on this table because in March 2008 JPMorgan had acquired the firm in an assisted sale to prevent it from filing for bankruptcy.

In fact, a closer look at Bear Stearns' particular story provides compelling evidence against the view that mortgage industry insiders profited at the expense of outsiders. The company began experiencing problems in June 2007. Two hedge funds managed by the firm had invested heavily in subprime-related securities and reported enormous losses, requiring Bear Stearns to inject capital into the funds to protect investors. Remarkably, Bear Stearns executives were major investors in these funds. ${ }^{26}$ In other words, the executives most likely to understand the subprime-lending process had made personal investment decisions that exposed them to subprime risk. ${ }^{27}$

Indeed, the large insider losses have led many researchers to question whether lenders actually even used the OTD model. Table 5, reprinted from Acharya and Richardson (2009), shows that issuing institutions retained enormous amounts of both the AAA-rated privatelabel MBS and the CDOs tied to their lower-rated tranches. This retention of subprimemortgage risk occurred "even though the 'originate and distribute' model of securitization that many banks ostensibly followed was supposed to transfer risk to those institutions better able to bear it, such as unleveraged pension funds" (Kashyap 2010, p. 1). ${ }^{28}$

\section{Fact 11: Mortgage market outsiders were the biggest winners}

When we turn to the winners the pattern is equally stark. The biggest beneficiary from the crisis was hedge fund manager John Paulson, who bought billions of dollars of credit

\footnotetext{
${ }^{26}$ See p. 244 of Muolo and Padilla (2010) for further details.

${ }^{27}$ Along these lines, Cheng, Raina, and Xiong (2012) show that managers involved in the securitization process were no less likely to buy houses at the peak of the bubble than the population in general.

${ }^{28}$ Erel, Nadauld, and Stulz (2011) take on the question of why banks held so many risky subprime securities on their books and conclude that the best explanation is that they did so to signal the quality of the pools of loans. In a sense, Erel, Nadauld, and Stulz (2011) is a perfect illustration of the arguments in Grossman and Hart (1980). Rather than withhold private information, agents have an important incentive to fully disclose information in order to obtain the best prices for their products.
} 
protection on subprime deals in 2006 and 2007. When those deals defaulted en masse at the end of 2007, Paulson made $\$ 15$ billion in profits (Zuckerman 2010).

Paulson and his lieutenant, Paolo Pellegrini, were complete mortgage industry outsiders. They had no investment experience in housing or mortgage markets and they had never traded mortgages before. Zuckerman (2010) discusses investors' lukewarm response to Paulson's sales pitches, quoting one potential investor as saying:

'Paulson was a merger-arb guy and suddenly he has strong views on housing and subprime,' [the potential investor] recalls. 'The largest mortgage guys, including [Michael] Vranos at Ellington, one of the gods of the market, were far more positive on subprime' (p. 126).

Furthermore, Paulson and Pellegrini explicitly attributed their success not to insights about the underwriting process, but rather to a successful bet on house prices. According to Zuckerman (2010), their conclusion that house prices were going to fall was based on a simple analysis of the time-series of house prices in the United States:

Housing prices had climbed a puny 1.4 percent annually between 1975 and 2000, after inflation was taken into consideration. But they had soared over 7 percent in the following five years, until 2005. The upshot: U.S. home prices would have to drop by almost 40 percent to return to their historic trend line (p. 107).

It was this simple insight about prices - not any fact about credit, the origination process, or moral hazard - that led Paulson and Pellegrini to gamble on bearish bets on the subprime mortgage market. The chart showing that house prices would fall 40 percent was Paulson's "Rosetta stone, the key to making sense of the entire housing market" (Zuckerman 2010, p. 108). And even Zuckerman seems surprised by the failure of the insider/outsider theory of mortgage markets, posing this question at the beginning of his book:

Why was it John Paulson, a relative amateur in real estate and not a celebrated mortgage, bond, or housing specialist like Bill Gross or Mike Vranos who pulled off the greatest trade in history? (p. 3)

Another winner, memorably described by Lewis (2010), was Michael Burry. His hedge fund Scion Capital made almost $\$ 1$ billion in profits using a similar strategy to Paulson, although on a smaller scale. Lewis writes that Burry, a medical doctor by training, was an outsider not only in the housing and mortgage industries but to society in general, as he worked largely alone. Burry attributed his success to his willingness to read complex prospectuses carefully: 
Burry had devoted himself to finding exactly the right ones to bet against. He'd read dozens of prospectuses and scoured hundreds more, looking for the dodgiest pools of mortgages, and was still pretty certain even then (and dead certain later) that he was the only human being on earth who read them, apart from the lawyers who drafted them. In doing so, he likely also became the only investor to do the sort of old-fashioned bank credit analysis on the home loans that should have been done before they were made (Lewis, 2010, p. 50).

In other words, Burry's bets were based on publicly available information.

Taking a broad view, the most useful demarcation to make when thinking about the mortgage market is not between insiders and outsiders, the division made in the top panel of Figure 1. Rather, it is between those people who thought house prices would continue to rise and those who were willing to bet that they would fall. Sadly for the economy, the overly optimistic group included not only the investors at the end of the securitization chain, but lenders and securitizers who sold them the bonds, and whose losses precipitated the financial crisis.

\section{Fact 12: Top-rated bonds backed by mortgages did not turn out to be "toxic." Top-rated bonds in collateralized debt obligations (CDOs) did.}

No discussion of the causes of the financial crisis would be complete without some discussion of the rating agencies. To some analysts, the simple fact that rating agencies gave AAA ratings to subprime securities is patently absurd. An AAA rating is supposed to signal a near-complete absence of credit risk. Yet these bonds were often backed by reduced documentation loans to borrowers with previous credit problems. Other critics are more specific, noting that the issuers paid the rating agencies to evaluate their deals. The implication is that for the agencies these payments generated a conflict of interest that encouraged them to bestow unjustifiably high ratings. At the very least, commentators often claim that rating agencies abetted finance industry insiders by endorsing securities backed by problem mortgages. Yet the facts paint a more nuanced picture.

To start with, the top-rated tranches of subprime securities fared better than many people realize. The top panel of Figure 9 is generated from data on AAA-rated bonds created in 2006 from private-label securitization deals. ${ }^{29}$ Specifically, the panel shows the fraction of these bonds on which investors suffered losses or, using industry jargon, the fraction that was "impaired." In some of these deals, 70 percent of the underlying subprime loans terminated in foreclosure (Jozoff et al. 2012). Yet despite these massive losses, the figure shows that investors lost money on less than 10 percent of private-label AAA-rated securities. How is

\footnotetext{
${ }^{29}$ These deals included subprime mortgages, Alt-A mortgages, and jumbo mortgages.
} 
that possible? As many have explained, the AAA-rated securities were protected by a series of lower-rated securities which absorbed most of the losses. If a borrower defaulted and the lender was unable to recover the principal, the resulting loss would be deducted from the principal of the deal's lower-rated tranches. For subprime deals, the degree of so-called AAA credit protection - the principal balance of the non-AAA securities - was often more than 20 percent. Given a 50 percent recovery rate on foreclosed loans, 20 percent credit protection meant that 40 percent of the borrowers could suffer foreclosure before the AAArated investors suffered a single dollar of loss. For riskier deals, credit protection was higher, often substantially so. The key takeaway is that for subprime securities, credit protection largely worked, and investors in the AAA-rated securities were largely spared.

The relatively robust performance of private-label AAA-rated securities is explained clearly in the final report of the Financial Crisis Inquiry Commission (2011), among other sources. Yet it still surprises many people. If these AAA-rated securities didn't suffer losses, where were the famous "toxic mortgage-related securities" that caused the financial crisis? The answer is that banks used lower-rated securities from private-label deals to construct other securities, such as the CDOs discussed earlier. Recall that because these CDOs were backed by tranches of subprime securities, which were technically labeled asset-backed securities (ABS), the resulting CDOs were called ABS CDOs. The main difference between the original ABS and the ABS CDOs was that the CDOs were not backed by 2,000 or so subprime loans, but rather a collection of 90-100 lower-rated tranches of subprime ABS deals, with most of these tranches having BBB ratings. Yet the organizing principal of CDOs and the original ABS securities was the same: senior AAA-rated tranches were protected from losses by lower-rated tranches. For the original ABS, losses would occur if individual homeowners defaulted. For the CDOs, losses would occur if the BBB-rated securities from the original ABS deals defaulted.

The bottom panel of Figure 9 shows the share of 2006 ABS CDOs that were impaired. The results are nearly the mirror image of the previous graph. Whereas investors suffered losses on less than 10 percent of the AAA-rated tranches from the original subprime securities, they suffered losses on all but 10 percent of AAA-rated ABS CDOs. ${ }^{30}$ To make matters worse, a large portion of the ABS CDOs were known as "super-senior" securities because they were senior even to the AAA-rated tranches of the CDO. Super-seniors were often retained by the Wall Street firm that issued the CDO. But CDO losses were commonly large enough to wipe out both the AAA tranches and super-senior ones, leaving the issuing institution with large losses. In short, it was the ABS CDOs, not the original subprime ABS, that proved so

\footnotetext{
${ }^{30}$ For a discussion of the link between CDOs and the underlying ABSs, see Ashcraft and Schuermann (2008).
} 
toxic to the financial system. And the main failure of the rating agencies was not a flawed analysis of original subprime securities, but a flawed analysis of the CDOs composed of these securities.

The disparate performance of top-rated tranches from ABS and CDOs is one of great puzzles of the crisis. Because issuers were paid to rate both types of securities, it is hard to blame the bad CDO ratings on the "issuer pays" model of rating-agency compensation. But if a conflict of interest did not cause the bad ratings on the CDOs, what did? Some institutional evidence provides a clue to the answer.

The key insight is that ABS and CDOs were evaluated by using very different methods. This was true both at the investment banks that issued these two types of securities and the agencies that rated them. When forecasting subprime ABS performance, analysts modeled the default probabilities of the individual loans. Recall that the data for this type of analysis was widely available, for example in the loan-level datasets collected and standardized by LoanPerformance. To forecast the performance of a subprime pool, analysts could first estimate an individual-level default model based on loan-level predictors like the credit score, the debt-to-income ratio, the interest rate, and the current level of the borrower's equity. The current equity level could be inferred by the original downpayment on the loan, the loan's amortization schedule, and the subsequent behavior of housing prices. Armed with an individual-level model of default, the analyst could then simulate what would happen to all the mortgages in the pool if housing prices declined by (say) 5 or 10 percent.

Three comments on this ABS analysis are in order to set up the contrast with the method used to evaluate CDOs. The first is that the ABS analysis was accurate. Recall the Lehman Brothers analysis from Table 2, which gives a basically accurate prediction for how bad ABS losses would be if housing prices declined. Second, in the jargon of economists, the analysis was structural, in that it modeled how individual decisions are likely to change as economic conditions evolve. Falling prices make it more likely that a homeowner will have negative equity, and economic theory predicts that "underwater" owners will default more often. ${ }^{31}$ This prediction receives a great deal of support in empirical default models, so analysts knew that defaults would rise if prices declined. Moreover, they knew that lower-rated tranches of subprime ABS would be wiped out if the price decline was especially large. This knowledge encouraged the issuers of subprime ABS to build a great deal of credit protection into their deals at the outset, in order to ensure that their top-rated bonds would pay off no matter what happened to the housing market.

\footnotetext{
${ }^{31}$ Underwater owners who lose their jobs or suffer some other adverse life event are unable to sell their homes for enough to pay off their loans. Foreclosure is often the only possible outcome in this case. Additionally, if negative equity is large enough, an underwater owner may simply walk away from his mortgage in a so-called ruthless or strategic default.
} 
A third point about the analysis of private-label mortgage securities is that this analysis could examine how correlation in individual mortgage defaults might arise. ${ }^{32}$ The basic idea behind securitization is that individual loans might have high individual probabilities of default, but these probabilities are not likely to be correlated with one other. This assumption is violated, however, if there is some aggregate shock to all the mortgages in a pool, for example if house prices declined on a nationwide basis. The loan-level models allowed analysts to predict how such a shock could affect mortgage pools, even though no such shock had occurred in recent history. The analysts simply noted how individual equity positions of homeowners would change if prices declined by some assumed amount. They could then use their models to generate expected default probabilities for individual loans, then add these probabilities together. Not surprisingly, these exercise implied that a common negative price shock would induce a large correlation in expected defaults. Mortgages across the country would be much more likely to default at the same time if house prices fell everywhere.

Unfortunately, this type of structural analysis was not performed by Wall Street's CDO analysts, who were organizationally independent of the researchers analyzing mortgage pools. The CDO analysts did not devise structural models for the individual BBB-rated tranches in their CDOs. Instead, they essentially skipped ahead to the step of asking how correlated BBB defaults were likely to be. To do this, the CDO analysts looked at past financial market data, including the prices of default insurance on individual BBB tranches. ${ }^{33}$ As it happened, the past data implied that default correlations among the BBB tranches were low. Tranches from some deals might might have paid better or worse than tranches from other deals, but there was never a time when large numbers of BBB tranches defaulted simultaneously. Crucially, the CDO analysts' backward-looking approach assumed that these low correlations would continue into the future. There was no way to model the effect of a nationwide decline in house prices because past data did not encompass such a decline. Of course, when national house prices did fall, the CDO analysts learned that defaults among BBB tranches were far more correlated than their methods had implied. As the mortgage analysts had predicted, the nationwide house price decline generated a massive correlation in defaults among individual mortgages, which wiped out the BBB tranches of the original subprime deals. Because these losses occurred on virtually all private-label securities at the same time, BBB tranches from

\footnotetext{
${ }^{32}$ A better label for this type of analysis might be "semi-structural," because it does not attempt to uncover deep parameters that are relevant to the default decision. For example, the analysis does not estimate the rate of time preference of individual homeowners, or how homeowners would value an extra dollar of wealth.

${ }^{33}$ In the past, if the price of default insurance for two BBB tranches went up at the same time, the CDO analysts would infer that the default probabilities of the two tranches were positively correlated as well. Note that this inference could be made even if neither of the two tranches had ever defaulted. See Salmon (2009) for a discussion of a mathematical formula called the Gaussian copula that aided this calculation and Coval, Jurek, and Stafford (2009) for a more general discussion.
} 
many different securities went bust at the same time too. As a result, CDO losses extended far into the AAA-rated and super-senior tranches, with disastrous implications for the financial system.

At one level, the institutional facts resolve the puzzle over disparate ABS and CDO performance because they provide a simple explanation for why rating agencies and banks viewed the two similar types of securities so differently. The different outlooks could have stemmed from the backgrounds of the two groups of analysts. CDOs were originally constructed from various corporate bonds, for which historical correlations have been excellent guides to future performance, even during the recent crisis. CDO analysts probably assumed that the same type of historical analysis would also work well for CDOs made up of subprime mortgage bonds. By contrast, mortgage analysts were trained to model mortgages individually, and they had the data and the tools to do so.

Yet the institutional facts deepen the puzzle as well. In hindsight, it is hard to see how two groups of analysts could work in close proximity at the same financial institution and not notice the colossal dissonance implied by their respective analyses. For example, during the peak of the mortgage boom, mortgage analysts at UBS published reports showing that even a small decline in house prices would lead to losses that would wipe out the BBB-rated securities of subprime deals (Zimmerman 2005). At the same time, UBS was both an issuer of and a major investor in ABS CDOs, which would be nearly worthless if this decline occurred. Why didn't the mortgage analysts tell their coworkers how sensitive the CDOs would be to a price decline? This question goes to the heart of why the financial crisis occurred. The answer may well involve the information and incentive structures present inside Wall Street firms. Employees who could recognize the iceberg looming in front of the ship may not have been listened to, or they may not have had the right incentives to speak up. If so, then the information and incentive problems giving rise to the crisis would not have existed between mortgage industry insiders and outsiders, as the inside job story suggests. Rather, these problems would have existed between different floors of the same Wall Street firm.

\section{Economic Theories and the Facts}

Our 12 facts consistently point to higher price expectations as a fundamental explanation for why credit expanded during the housing boom. In this section, we ask what could have generated those higher expectations. Theories of asymmetric information argue that mortgage originators failed to adequately screen loans and passed them on to unsuspecting investors in mortgage-backed investments. The resulting expansion in credit then drove prices higher. Some of our facts have argued directly against this line of reasoning; in this section, 
we show that explanations based on asymmetric information fail on theoretical grounds as well. A second group of explanations claims that mortgage market developments related to financial innovation allowed credit to expand and prices to rise. We show that these explanations also have theoretical and empirical problems. Finally, we discuss the only set of theories left standing. These theories claim that the U.S. housing market was a classic asset bubble, just like previous bubbles in tulips and tech stocks.

\subsection{Explanations based on asymmetric information}

Economists have long studied what happens when sellers knows more about the good being traded than buyers do. A key insight from this research can be conveyed with a simple example. Suppose you see an advertisement for a one-owner 1995 Oldsmobile Cutlass Ciera on Craigslist with an asking price of $\$ 1,500$. You reason that a lightly driven Ciera built in 1995 should have about 100,000 miles on it, making it worth about $\$ 1,500$ to you. So you call the seller and tell him you are interested, through you would like to know how many miles are on the car. The seller responds that the odometer reads about 90,000 miles, but he does not know the mileage for sure, because the odometer has stopped working. The owner is pretty sure, however, that the odometer broke only last month, so the 90,000-mile figure should be about right.

Given these facts, how much would you be willing to pay for the car? Certainly not $\$ 1,500$, and most likely much less. Even though the seller reports a mileage that is less than 100,000 miles, you cannot verify this information yourself because the odometer does not work. Further, you realize that if the odometer had actually broken several years ago, the seller would have no incentive to tell you the truth. Perhaps most importantly, you realize that not all owners of 1995 Cieras are trying to sell them; many are happily driving them. ${ }^{34}$ The willingness of this particular owner to part with his Ciera indicates that he may know something bad about it that you don't-like its true mileage. Given all this, you are likely to offer a very low price for the Ciera or refuse to buy it altogether.

In this example, you as the potential buyer are at an informational disadvantage. The seller (the informed insider) has years of experience with the car while you (the uninformed outsider) do not even know its true mileage. Even so, you recognize the seller's incentives and understand that some information about the car is unverifiable. Then, by using common sense, you are able to form what is most likely an accurate view of the car's value, some amount less than $\$ 1,500$. This simple example illustrates a bedrock result in the theory of asymmetric information: uninformed parties who trade with informed parties do not usually

\footnotetext{
${ }^{34}$ One of the authors of this paper provides an example.
} 
get exploited. The uninformed parties not only realize they are uninformed, they also realize that the informed party will try to use his superior information to exploit them. ${ }^{35}$

How does the used-car example relate to securitization and the mortgage market? In the securitization process, lenders screen potential borrowers and originate mortgages, then package the mortgages for sale to outside investors. Yet investors cannot verify how carefully the screening is actually done. The problem is worse if the lender retains no skin in the game, so that any credit losses on the mortgages are borne solely by the investor. ${ }^{36}$ Given these informational problems, it is reasonable to think that investors would be concerned about purchasing any mortgage-backed securities. This is the prediction of textbook theories of asymmetric information, which imply that if such asymmetries had been a problem for mortgage-backed securities, we would not have seen an explosion of securitized mortgage credit driving housing prices higher while investors were cheated. Rather, the opposite would have occurred. Mortgage credit would have dwindled as investors, like buyers looking over used cars with broken odometers, walked away from the deals.

Yet even though buying and selling mortgages involves some degree of asymmetric information, securitized mortgage credit did explode and house prices did move higher. The best explanation for this correlation places higher price expectations at the front of the causal chain. If investors believed that housing prices would continue rising rapidly, then it didn't matter what a mortgage borrower's income or credit score was. In the event that the borrower defaulted, then the higher price of the house serving as collateral would eliminate any credit losses. ${ }^{37}$ In the words of Gorton (2010), higher housing prices cause securitized mortgages to become less "information sensitive," meaning that their profitability depends less on potentially unverifiable characteristics like borrower credit scores and incomes. So in the early 2000s, when price expectations rose, investors became eager to invest in securitized mortgages - even those that were clearly identified as "reduced documentation"' or "no documentation," for which originators avowed that the loans had not been painstakingly underwritten.

Some authors have tried to rescue the asymmetric-information theory of the crisis by

\footnotetext{
${ }^{35}$ Akerlof (1970) shows what happens when this result is carried out to a logical conclusion. If sellers of goods are unable to convey their quality to potential buyers, then the buyers assume that the quality of the goods being offered is low. Consequently, the buyers bid only low prices. These low prices encourage the sellers that really do have high-quality goods to pull them off the market, further depressing the average quality of goods offered for sale. Buyers then further reduce their offers. In equilibrium, trade can break down completely, so that welfare-improving exchanges between buyers and sellers do not occur.

${ }^{36}$ In this case, the used-car analogy is especially appropriate, because the seller of the Ciera will not be responsible for any repair bills after he transfers title to the car.

${ }^{37}$ In reality, a financially stressed mortgage borrower who had built up substantial positive equity would probably not default in the first place, because he could sell the house, pay off his mortgage, and still have money left over.
} 
arguing that investors didn't know about the information problems involved, or that they were too trusting of mortgage originators. The claim is that in the future, investors won't be fooled again, but in 2007-08, their naiveté caused massive losses. Perhaps the most famous example of such a claim is Mian and Sufi (2009), which references an "undetected moral hazard on behalf of originators selling [mortgages] for the purpose of securitization as a potential cause for higher mortgage default rates" (p. 1482, emphasis and insertion added).

The naive investor theory can be thought of as an out-of-equilibrium behavior in a standard asymmetric information model. Equilibria in these models posit that buyers that do not get cheated, but this result assumes that buyers recognize both their informational disadvantage and the willingness of sellers to exploit it. The problem with this theory is that the facts do not support it. To make an obvious point, many Wall Street investors who lost money were seasoned financial professionals, a group generally not known for being overly trusting of those on the other side of high stakes deals. More importantly, facts 3 and 5 showed that the institutional framework behind mortgage securitization was not new. Investors had ample time to discern the relevant incentives and act accordingly. Public discussions of potential moral hazard issues surrounding mortgage-backed securities had been common as well. Recall the quote from housing industry journalist Lew Sichelman, who noted with alarm that lenders were originating low documentation loans for sale to investors - in 1990. Years later, when the subprime market was peaking, the front page of the "Money and Investing" section of the Wall Street Journal also highlighted the potential for moral hazard:

Lenders have long sold all or most of their standard mortgage loans to packagers of securities backed by these assets. But when it comes to riskier loans, some investors like to see lenders retain a large amount of exposure, so that both lenders and investors have skin in the game (Simon and Hagerty 2005).

In short, the idea that the underwriting standards of lenders who sold loans might be different from the standards of portfolio lenders is not a sophisticated idea from a graduate seminar in information economics. Rather, it is a simple concept that was understood by virtually everyone. It does not imply that well-informed insiders were able to expand credit by taking advantage of ill-informed or neophyte outsiders. Instead, it implies that higher price expectations expanded credit by lessening the impact of any informational problems inherent in the securitization process.

The strong growth in low-doc and no-doc lending during the housing boom provides the clearest example of how informational problems were pushed to the background by higher price expectations. As the lower left panel of Figure 3 shows, the use of such loans exploded from 2002 to 2006. The growth of reduced-documentation lending is often presented as 
Exhibit A in narratives of how the declining standards of mortgage lenders caused the housing crisis. What this growth really shows is the declining standards of investors. These loans were clearly marked as "stated income, stated assets" loans, so investors knew what they were getting. In particular, investors knew that borrowers were likely to have inflated their incomes and assets. Yet investors purchased the loans anyway because they expected these loans to be profitable. ${ }^{38}$ For later commentators to complain that lenders did not bother to verify income or employment is like complaining that McDonald's sometimes sells hamburgers without cheese on them. McDonald's sells hamburgers because some people prefer them to cheeseburgers. Low-doc and no-doc loans were sold because some investors preferred them to loans for which incomes and assets had been rigorously verified. Investors were willing to take their chances with the riskier loans because they thought that higher house prices would make that risk worth taking, not because of misaligned incentives in the securitization process.

It is important to reiterate that information economics implies that informed sellers generally prefer to trade with informed buyers, not uninformed buyers. The reason for this seemingly counterintuitive result is that uninformed buyers are likely to be suspicious. Returning to our used car example, the broken odometer means that potential buyers will be uninformed about the true mileage of the car and thus suspicious about the car's true condition. Consequently, even if the Ciera is in exceptionally good condition, the seller will never get a good price for it. In other words, the broken odometer confers an informational advantage to the seller, but this is an "advantage" that the seller would very much like to avoid. The implication for mortgage markets is that originators would prefer to trade in more transparent markets. Some have suggested that Fannie Mae and Freddie Mac did a better job of aligning incentives than the issuers of private label securities. But if that were true, then information economics would predict that sellers would have been reluctant to trade in the private label market, where the informational asymmetries were more severe and prices were likely to be lower.

Finally, while asymmetric information may not have driven a credit expansion during the housing boom, this is not to say that asymmetric information played no role in the crisis. However, the truly damaging asymmetric information problem was not between investors and originators but between trading counterparties in the acute phase of the crisis. During this phase, market participants knew that financial institutions were facing hundreds of billions of dollars of losses, but it was unclear precisely where these losses would fall. In a sense, many financial institutions were like cars with broken odometers and, as economic theory predicts,

\footnotetext{
${ }^{38}$ Indeed, investors often preferred reduced-documentation loans because of their superior prepayment properties. See Adelson (2003) for a more detailed discussion.
} 
trading ceased. Whatever role that asymmetric information among potential counterparties played in the crisis, it obviously cannot explain the decisions made by borrowers or investors before the crisis, which is the focus of this paper. Asymmetric information probably also figured in the decisions of lenders regarding mortgage modifications. Most borrowers who default have negative equity, but most negative equity borrowers do not default. Because lenders are unsure of the borrowers who really do need modifications to stay in their homes, they are likely to deny modifications to everyone (Foote, Gerardi, and Willen 2008; Adelino, Gerardi, and Willen 2009). Even though both borrowers and lenders are better off if modifications are given to the truly needy, asymmetric information prevents those Pareto-improving trades from occurring.

\subsection{Theories based on financial innovation}

A second group of theories argue that the source of rising house prices was some fundamental change in mortgage market institutions, though this change may not have resulted from asymmetric information. One possible example is a decline in downpayments required of potential home buyers. Researchers have constructed careful, fully optimizing models that imply financial innovations will raise house prices, by essentially shifting out the effective demand curve for owner-occupied homes. A key goal of these papers is to explain the run-up in prices without having to resort to irrational asset price bubbles.

Four comments about financial-innovation theories are in order. First, it may seem intuitive that financial innovation causes higher asset prices but economic theory makes no such prediction. In fact the one "folk theorem" from the literature is that a financial innovation, by improving risk sharing, reduces the demand for precautionary saving and lowers asset prices. $^{39}$

A second and more fundamental point is that a model of a financial innovation that generates an increase in asset prices typically cannot generate the subsequent fall in prices necessary to trigger a crisis. As a general rule, price movements in fully optimizing models are sustainable; to our knowledge, the phrase "unsustainable price increase" does not appear in any standard asset-pricing textbook. ${ }^{40}$ Without an exogenous change in the innovation that caused prices to go up in the first place, optimizing models simply cannot generate asset price declines.

In a leading example of the financial innovation approach, Favilukis, Ludvigson, and

\footnotetext{
${ }^{39}$ Elul (1997) shows that the folk theorem isn't quite true. With sufficient market incompleteness, one can always find an innovation that raises asset prices. Yet the folk theorem remains valid for virtually all parameterized models in macroeconomics and finance.

${ }^{40}$ Neither the word "unsustainable" nor any synonym appears in Cochrane (2005), for example.
} 
Van Nieuwerburgh (2010) develop an elegant general equilibrium model and attempt to replicate the path of U.S. house prices from 2002 to 2011. Specifically, they contend that the observed movement in the price-rent ratio for houses can be explained in an optimizing model by relaxed credit constraints (in the form of lower required downpayments) and lower transactions costs (including lower closing costs). ${ }^{41}$ The analysis in the paper is correct but, in our opinion, the authors come to the wrong conclusion. Rather than illustrating how financial innovations caused the housing crisis, in our view the model perfectly illustrates how financial innovation could not have caused it.

To see why we think Favilukis, Ludvigson, and Van Nieuwerburgh (2010) shows the impossibility of the financial innovation story as an explanation of the crisis, note that there is nothing "unsustainable" about the price increase that financial innovation is supposed to have generated. As a result, to be consistent with the 2006-08 fall in housing prices, the authors must presume that the economy underwent "a surprise reversal of the financial market liberalization" in 2006. The liberalization does not end because it was unsustainable - that is, because it was not justified by fundamentals. In particular, the liberalization does not end because borrowers have trouble repaying their debts, as all borrowers repay in full by assumption. Rather, the reversal occurs exogenously because it is the only way the model has any chance to explain the data. In particular, to generate a substantial fall in house prices, the authors must not only impose a massive reversal but also the ex ante belief among market participants that such a reversal cannot happen. If homebuyers had suspected that future borrowers would be unable to access the same financial innovation that they could access, then these homebuyers would not have bid up house prices so much. Put simply, the more likely the financial reversal, the smaller the initial increase in prices.

If Favilukis, Ludvigson, and Van Nieuwerburgh (2010) had been written before the housing market crash in 2006, housing optimists could have pointed to it as evidence that prices were on a permanently high plateau. There would have been no need to worry that the U.S. housing market was experiencing a bubble, as house prices could be shown to be consistent with a forward-looking and fully optimizing model. Now that prices have fallen, the paper implies that policymakers could revive the housing market easily by undoing whatever exogenous reversal caused it to contract. Of course, the inability of a rational model to explain the evolution of house prices is not unique to Favilukis, Ludvigson, and Van Nieuwerburgh

\footnotetext{
${ }^{41}$ The authors also show that a coincident inflow of foreign capital can keep interest rates low as this financial liberalization raises the demand for loanable funds. "Without an infusion of foreign capital, any period of looser collateral requirements and lower housing transactions costs (such as that which characterized the period of rapid home price appreciation from 2000-2006) would be accompanied by an increase in equilibrium interest rates, as households endogenously respond to the improved risk-sharing opportunities afforded by a financial market liberalization by reducing precautionary saving" (p. 3). The inflow of foreign capital plays only a small role in generating higher housing prices, however.
} 
(2010). The Achilles heel of all rational financial innovation models is that if the innovation is not expected to be permanent, then prices will not respond to it. So all credible financial innovation models have to include exogenous and surprising reversals of the innovations to be consistent with both the real-world collapse in prices and their own internal logic.

A third point about financial liberalization models is empirical. To generate the massive increase in housing prices from 2002 to 2006, financial innovation models must assume that the market innovations were profound. To return to Favilukis, Ludvigson, and Van Nieuwerburgh (2010), the authors assume that in 2002, required downpayments collapsed, falling from 25 percent to only 1 percent. To justify such a large change, the authors claim that,

prior to the housing boom that ended in 2006, the combined LTV for first and second conventional mortgages (mortgages without mortgage insurance) was rarely if ever allowed to exceed 75 to 80 percent of the appraised value of the home (p. 42).

Facts 4 and 6 show that this statement is not even approximately true: a combined LTV of 100 percent was available in 1944 and the majority of borrowers borrowed more than 80 percent as far back as 1992. To make matters worse, Figure 6 shows that, at least as far as downpayments were concerned, there is no evidence of the exogenous reversal in lending standards needed to explain the house price decline. The share of borrowers putting less than 5 percent down in 2011 was higher than this share had been in any year prior to the crisis. In short, the data provide no foundation to believe either that a dramatic policy change occurred in 2002 or that any change was reversed in 2006, when house prices began to fall.

The fourth and final point about financial innovation is that financial market innovations are exogenous changes. Such changes can occur as consequences of new laws. For example, in the 1980s, the federal government passed passed laws intended to address rising interestrate risk among lenders. Gerardi, Rosen, and Willen (2010) point out that these laws had the collateral effect of eliminating Depression-era limits on innovation in mortgage markets. The Monetary Control Act of 1980 allowed regulated lenders to make true adjustable-rate mortgages, including option ARMs. The Secondary Mortgage Market Enhancement Act of 1984 and the 1986 Tax Act paved the way for private-label securitization. No comparable exogenous shocks occurred from 2002 to 2004. Ironically, as explained in Fact 3, it was the 1980s innovations that made the more intensive use of alternative mortgage products possible in the 2000s. Researchers who argue that innovations occurred in the 2000s often point to the origination data in Figure 3 which shows changes in the characteristics of underwritten loans - smaller downpayments, more interest-only loans, less documentation-but these are all endogenous variables. Only if the option ARM had been invented in 2002 could one 
possibly argue that its growth was exogenous. But as we have seen, this loan had been around and widely used for 20 years prior to the boom.

Ultimately, the lesson of financial innovation models is that it is impossible to explain the dynamics of U.S. housing prices in the 2000s with a dynamic forward-looking general equilibrium model. Researchers should turn their attention to less-conventional approaches, such as those based on distorted beliefs. ${ }^{42}$ We discuss those models next.

\subsection{Theories based on bubbles and distorted beliefs}

Economists are fascinated by bubbles and have been for a long time. On a number of occasions, speculative fervor has gripped some asset, leading to prices that outstrip any realistic estimate of the future income that this asset could generate. When no more buyers for this asset are forthcoming - when the music stops - the prices crashes. Bubbles and crashes commonly arise in the laboratories of experimental economists, where volunteer test subjects buy and sell simulated assets under controlled conditions. ${ }^{43}$ Unfortunately, a comprehensive logical framework to analyze and explain bubbles continues to elude the economics profession. Models have been developed to explain why bubbles can persist for a long time, but as Brunnermeier (2008) notes, "[W]e do not have many convincing models that explain when and why bubbles start."

Certainly, there is no general theoretical result linking bubbles to financial innovation. In fact, some theoretical results show just the opposite effect, as financial innovation brings the asset price more in line with its fundamental value. ${ }^{44} \mathrm{~A}$ link between financial innovation and bubbles is also unsupported by the historical record. In the 1930s, many blamed the U.S. stock market bubble of the 1920s on financial innovations that allowed firms and individuals to increase leveraged positions in stocks. Consequently, the regulatory framework that emerged from the Great Depression placed severe limits on leverage in the equity market. But that regulation did not prevent the technology bubble of the 1990s, although it may have prevented the subsequent collapse in stock prices from causing a financial crisis. ${ }^{45}$

Yet if we are willing to accept that the U.S. housing market was in a bubble during the early-to-mid 2000s, then the decisions of both borrowers and lenders are understandable. To grasp the role of higher expected prices from an investor's perspective, return to Table

\footnotetext{
${ }^{42}$ For some examples of this type of research, see the citations in footnote 1.

${ }^{43}$ For a classic early example of bubbles in a laboratory, see Smith, Suchanek, and Williams (1988). Looking back at the large literature that this study initiated, Porter and Smith (2008, p. 247) note that bubbles and crashes are "standard fare" in lab experiments with inexperienced test subjects. Prices adhere more closely to fundamental values if subjects are allowed repeated opportunities to trade.

${ }^{44}$ For an example, see Miao and Wang (2011).

${ }^{45}$ We will have more to say about the relationship between financial crises and asset price collapses in our concluding section.
} 
2. First, high price expectations can explain why investors thought subprime mortgages were such a good investment. The average coupon on subprime adjustable-rate mortgages was several hundred basis points above the comparable prime loan. And yet, if investors think that house prices can rise 11 percent per year, expected losses are minimal. This line of thought also illustrates why the envelope of available mortgage credit expanded to such a great extent. Zero-down loans, subprime mortgages, negative amortization, and reduced documentation all make sense if prices are expected to grow rapidly, since it is the value of the house - not the borrower's income - that guarantees repayment of the loan. A bubble also rationalizes the decisions of borrowers. All models of household portfolio choice generate a close relationship between the level of expected returns on risky assets and household leverage. If a risky asset (like a house) pays a return that exceeds the risk-free rate, then borrowing a dollar and investing in the risky asset is a better-than-fair bet. The higher the expected return, the more better-than-fair the bet is. In fact, standard models imply that the demand for the risky asset is linear in the difference between the expected return on the risky asset and the risk-free rate. ${ }^{46}$ That means that if the mortgage interest rate is (say) 5 percent and the expected return on housing increases from 6 percent to 7 percent, then the demand for housing doubles.

Higher price expectations can also explain why so much mortgage credit was allocated to low-wealth households and why this allocation occurred through securitization. Higher price expectations encourage all households to increase their exposure to the housing market, but households with significant wealth can finance this increase by reducing their investment in bonds. Households with little or no wealth can finance an increase only through increased borrowing. Consequently, even the most basic portfolio choice model implies both the increase in mortgage debt and its distribution to low-wealth households.

The allocation of credit toward credit-constrained households also makes sense from the investor's point of view. High price expectations dramatically reduced the expected losses on subprime loans, but had little effect on expected losses for prime loans, which were minimal to begin with due to their much higher credit quality. Consequently, the statement that "mounting evidence that much of the boom and bust was concentrated in low-income housing" in no way contradicts the validity of the bubble explanation. ${ }^{47}$ To our knowledge, no one has disputed the fact that from 2002 to 2006, credit availability increased far more for subprime borrowers than for prime borrowers - this growth was widely discussed as it occurred. ${ }^{48}$ These differential patterns in the credit expansion simply reflect a basic fact:

\footnotetext{
${ }^{46}$ For example, see equation (29) in Merton (1969).

${ }^{47}$ The quoted statement comes from Rajan (2010, p. 130).

${ }^{48}$ Additionally, the evidence that credit was expanding to low-income households was "mounting" as early as 2005. Simon (2005) and National Mortgage News (2005) are two of literally thousands of articles about
} 
relaxing a constraint only affects households who are constrained to begin with.

Finally, we have already seen that high prices can explain the growth of mortgage securitization. Because an individual borrower's characteristics no longer affect loss estimates as much when the underlying collateral is expected to rapidly appreciate, there is little incentive for the originator to gather information on these characteristics, or equivalently for the investor to ask for it. As a result, the originator ends up with less private information relative to an environment in which expected price growth is lower. As Dang, Gorton, and Holmström (2010) point out, this "symmetric ignorance" actually facilitates trade.

It is important to stress that while we are deeply skeptical of the theory that securitization caused the crisis by introducing information asymmetries, we are sympathetic to the idea that securitization had some role in the financial crisis. Securitization cut out the middleman and allowed a direct link between borrowers and investors. Rather than depositing money in a financial institution which then had discretion over where to lend, securitization allowed investors to target their money directly to a specific market-housing, in this case. Under normal circumstances, this is a good thing. But in the housing mania of the mid-2000s, securitization worked like Othello loved - not wisely, but too well. Indeed, the inefficiency of a more traditional financial system might have proved a blessing during this time, as it could have prevented overly optimistic borrowers and investors from finding each other.

Of course, it is deeply unsatisfying to explain the bad decisions of both borrowers and lenders by citing a bubble without explaining how the bubble arose. One speculative story begins with the idea that some fundamental determinants of housing prices caused them to move higher early in the boom. Perhaps the accommodative monetary policy used to fight the 2001 recession, or higher savings rates among developing countries, pushed U.S. interest rates lower and thereby pushed U.S. housing prices higher. Additionally, after the steep stock market decline of the early 2000s, U.S. investors may have been attracted to real estate because it appeared to offer less risk. The decisions of Fannie Mae and Freddie Mac may have also played a role in supporting higher prices. Without speculating about the reasons for their investment decisions, it is beyond dispute that Fannie Mae and Freddie Mac were major players in the lending boom of the 2000s, even if much of this lending occurred outside of their traditional guarantee business. Specifically, both Fannie Mae and Freddie Mac indirectly invested heavily in risky mortgages by buying AAA tranches of subprime and Alt-A mortgage-backed securities and holding these securities in their retained portfolios. Figure 10 shows the aggregate amount of subprime and Alt-A MBS that the GSEs purchased for their retained portfolios between 2000 and 2007. The GSEs absorbed between 30 and 40 percent of subprime MBS and between 10 and 20 percent of Alt-A MBS over the boom

the growth of subprime credit in 2005 . 
years, except for 2007, when the collapse of the market meant that the GSEs took almost all the subprime issuance. The GSEs were limited to the AAA-rated portions of the deals. For subprime deals, AAA typically accounted for about 80 percent of the security issuance by dollar value. This high percentage meant that in many of the boom years, the GSEs accounted for half of the subprime AAA-rated securities. ${ }^{49}$

What we do not know is how any modest increases in house prices brought about by developments like these morphed into a full-blown housing bubble, in which prices continued to rise under their own momentum to levels that far exceeded their fundamental values. Perhaps people simply noticed the original price increases and expected them to continue indefinitely. These optimistic price expectations encouraged buyers to offer high prices for houses, making the optimistic price expectations self-fulfilling - the hallmark of an asset bubble. Of course, the unanswered question is why this bubble occurred in the 2000s and not some other time. Unfortunately, the study of bubbles is too young to provide much guidance on this point. For now, we have no choice but to plead ignorance, and we believe that all honest economists should do the same. But acknowledging what we don't know should not blind us to what we do know: the bursting of a massive and unsustainable price bubble in the U.S. housing market caused the financial crisis.

\section{Policy Implications}

Determining the origin of the financial crisis is not merely an idle academic pastime, because alternative explanations imply different policy responses. To illustrate the issues involved, consider the optimal policies related to two types of noneconomic catastrophes: a malaria epidemic and an earthquake.

During the past 120 years, scientists have learned a lot about malaria. They know that malaria is caused by microscopic parasites - not "bad air," as originally thought - and they know that it is transmitted by mosquitos. Armed with their empirically validated theories, public health officials can take steps to prevent the disease from spreading, for example by eliminating pools of standing water where mosquitos breed. ${ }^{50}$ Earthquakes are another

\footnotetext{
${ }^{49}$ One popular perspective is that the purchases were driven primarily by the Congressionally mandated affordable housing goals in the so-called GSE Act of 1992. This Act, formally titled the Federal Housing Enterprises Financial Safety and Soundness Act, mandated that a proportion of each GSE's annual mortgage purchases come from low-income households and low-income and minority neighborhoods. However, an emerging empirical literature has attempted to directly measure the impact of the GSE affordable housing goals on the volume of mortgage originations. For the most part, this literature has found negligible effects (Bhutta 2010; Moulten 2010; Ghent, Hernandez-Murillo, and Owyang 2012).

${ }^{50}$ See the description of how U.S. Army doctors attacked yellow fever and malaria during construction of the Panama Canal in McCullough (1977).
} 
matter. Science has a theory of why earthquakes occur, but quakes strike without warning and there is nothing we can do to prevent them. Even so, policymakers can mitigate their consequences. The Loma Prieta earthquake that hit San Francisco in 1989 and the Port-auPrince quake of 2010 were of roughly the same magnitude. But while 200,000 people died in Haiti, only 60 died in San Francisco. The difference was that in San Francisco, officials created and enforced rigorous building codes. As geologists say, "Earthquakes don't kill people - buildings do." ${ }^{51}$

For policymakers, the important question is whether the economic events of 2002 to 2008 were more like malaria or more like an earthquake. Was the crisis a "preventable disaster," resembling a disease whose pathology is well-understood and for which we can administer an effective treatment? ${ }^{52}$ Or, to draw on the Nocera quotation from the introduction, was the crisis instead caused by a poorly understood "mass delusion" that we can neither predict nor prevent? Proponents of the conventional wisdom on the crisis clearly view it like malaria. A great deal of policy since the crisis has focused on improving disclosure and changing incentives for financial intermediaries. But we are skeptical that this approach will work.

Consider the Dodd-Frank requirement that loan originators retain 5 percent of the credit risk of certain mortgages. During the housing boom, would this requirement have stopped lenders from making bad loans? In 2006 and 2007, lenders originated $\$ 791$ billion subprime loans. ${ }^{53}$ Had Dodd-Frank existed, lenders would have retained 5 percent of that amount or $\$ 40$ billion of subprime credit. Overall loss rates of 35 percent would have saddled them with $\$ 14$ billion in losses. ${ }^{54}$ Inspection of Table 4 shows that mortgage-related losses exceeded that amount for no fewer than eight firms individually. In other words, if every one of those firms had followed the Dodd-Frank requirement and originated the entire subprime mortgage market, they would have suffered smaller losses than they actually did.

In addition, many analysts have argued that if the managers of financial institutions had had their own money at stake, they would have been more careful (Rajan 2010, p. 164-165). But the losses suffered by Jimmy Cayne and Richard Fuld, the CEOs of Bear Stearns and Lehman Brothers, dwarf by an order of magnitude any clawback provision contemplated so far. And further down the organization chart, Lehman staff owned nearly a third of the company, so many managers obviously had significant skin in the game as well (Sorkin 2010, p. 294)..$^{55}$

\footnotetext{
${ }^{51}$ See Hough and Jones (2002).

${ }^{52}$ The quotation comes from Warren (2010).

${ }^{53}$ See the 2011 Mortgage Market Statistical Annual (Inside Mortgage Finance Publications 2011).

${ }^{54}$ The 35 percent figure is calculated using actual originations from the 2008 Mortgage Market Statistical Annual, Table II.A.1 (Inside Mortgage Finance Publications 2008) and cumulative losses for the relevant vintages using Jozoff et al. (2012).

${ }^{55}$ See also the discussion in Fahlenbrach and Stulz (2011). Bebchuk, Cohen, and Spamann (2010) argues
} 
Provisions to help borrowers understand their mortgages are also likely to be ineffective. The vast majority of borrowers who defaulted on their loans did so facing a payment amount that was the same or lower as when they first got their mortgage, so how could clearer terms have helped? Moreover, the idea that borrowers are the victims of confusing transactions is not remotely new, indeed it was the premise behind the 1968 Truth in Lending Act as well as the 1974 Real Estate Settlement Procedures Act. Real estate regulators have been working on a "simple form that conveys all the relevant information" for more than 40 years. Further, policymakers recognized the benefits of condensing all the costs of a financial product into a single number long before the emergence of behavioral economics, which is why the the inscrutable annual percentage rate (APR) is now enshrined in law. Many people ridicule the APR - until they try to come up with something better.

If borrowers and investors made bad decisions due to a collective belief that housing prices would rise rapidly and could never fall, then better disclosures, simpler products, and improved incentives for intermediaries would have made little difference. But that does not mean that policy is always ineffective. Even though scientists cannot predict or prevent earthquakes, robust building codes still prevent millions of deaths. How can we create a bubble-resistant financial system? Many new regulations, including some in Dodd-Frank, are designed to make the financial system more robust. We suggest two questions that can be asked in evaluating future policy designs.

First, can financial institutions withstand a serious house price shock? It is not unreasonable to ask if a financial institution could withstand a 20 percent decline in house prices without any liquidity problems. It is important to consider such scenarios even when they appear remote. For example, just because house prices have already fallen 20 percent does not mean they cannot fall another 20 percent. As Table 3 illustrates, some analysts were convinced that a bottom had been reached for house prices in 2006. And after long periods of stability, even sophisticated analysts are tempted to declare that economic fluctuations are a thing of the past. Recall that in the mid-2000s, economists were puzzling about what appeared to be a permanent reduction in macroeconomic volatility.

Second, can borrowers withstand a substantial fall in house prices? Warren and Tyagi (2004) argue that families could practice a "financial fire drill," which would ask how they would get by if one income-earner lost a job. A fire drill could also include a scenario in which falling house prices prevent the family from the selling their house for more than they owe on their mortgage. Effectively, such a fire drill would be similar to so-called stress tests that regulators conduct at financial institutions.

that managers did make large profits earlier but does not dispute that they had large amounts of their own money at stake when the firms collapsed. 
Finally, everyone - from first-time homebuyers to Wall Street CEOs - needs to recognize that asset prices move in ways that we do not yet understand. Unfortunately, none of the new mortgage disclosure forms proposed by regulators includes the critical piece of information that borrowers need to know: there is a chance that the house they are buying will soon be worth substantially less than the outstanding balance on the mortgage. If this happens and the borrower does not have sufficient precautionary savings, then that borrower is one job loss or serious illness away from default.

Critics might contend that treating bubbles like earthquakes is reminiscent of a doctrine often associated with Alan Greenspan: policymakers should not try to stop bubbles, which are not easily identified, but should instead clean up the damage left behind when they burst. To some extent, we concur with this doctrine, because we believe that policymakers and regulators have little ability to identify or to burst bubbles in real time. ${ }^{56}$ Yet this strategy works only when the financial system is robust to adverse shocks.

As we mentioned earlier, the reforms of the 1930s failed to prevent a bubble from forming in the stock market in the late 1990s. But the early 2000s stock market collapse did not lead to an economic crisis or to widespread financial problems among households. Why not? One possible explanation is that the reforms of the 1930s made the financial system "bubble resistant," at least for equities. Our hope is that we can achieve something similar with housing in the future. But for that to happen, housing policy must be based on the facts.

\footnotetext{
${ }^{56}$ We know of no central bank that has successfully managed a bubble. In the early 1990s, the Japanese central bank was credited with engineering an end to the bubble in Japan, but few central bankers would use that as a model for policy today.
} 


\section{References}

Acharya, Viral V., and Matthew Richardson, eds. 2009. Restoring Financial Stability: How to Repair a Failed System. New York: John Wiley \& Sons.

Adelino, Manuel, Kristopher Gerardi, and Paul S. Willen. 2009. "Why Don't Lenders Renegotiate More Home Mortgages? Redefaults, Self-Cures and Securitization." Working Paper No. 15159. Cambridge, MA: National Bureau of Economic Research.

Adelson, Mark. 2003. "A Journey to the Alt-A Zone: A Brief Primer on Alt-A Mortgage Loans." Nomura Fixed Income Research, June 3, 2003.

Akerlof, George A. 1970. "The Market for "Lemons": Quality Uncertainty and the Market Mechanism." Quarterly Journal of Economics 84(3): 488-500.

Arnold, Chris. 2009. "Forcing Banks To Put More 'Skin In The Game'." National Public Radio, June 18, 2009. Available at http://www.npr.org/templates/story/story.php? storyId=105558991.

Ashcraft, Adam B., and Til Schuermann. 2008. "Understanding the Securitization of Subprime Mortgage Credit." Federal Reserve Bank of New York Staff Report No. 318. Available at http://www.newyorkfed.org/research/staff_reports/sr318.pdf.

Bair, Sheila C. 2007. "Statement on Possible Responses to Rising Mortgage Foreclosures." Testimony before the House Financial Services Committee, April 17, 2007. Available at http://www.fdic.gov/news/news/speeches/archives/2007/chairman/spapr1707. html.

Barberis, Nicholas. 2011. "Psychology and the Financial Crisis of 2007-2008." Yale University Working Paper. Available at http://faculty.som.yale.edu/nicholasbarberis/cp10. pdf.

Bebchuk, Lucian A., Alma Cohen, and Holger Spamann. 2010. "The Wages of Failure: Executive Compensation at Bear Stearns and Lehman 2000-2008." Yale Journal on Regulation $27(2): 257-282$.

Bhutta, Neil. 2010. "GSE Activity and Mortgage Supply in Lower-Income and Minority Neighborhoods: The Effect of the Affordable Housing Goals." Journal of Real Estate Finance and Economics (Online First). 
Brunnermeier, Markus K. 2008. "Bubbles." In The New Palgrave Dictionary of Economics, eds. Steven N. Durlauf and Lawrence E. Blume, second edition. Basingstoke: Palgrave Macmillan. Available at http://www.dictionaryofeconomics.com/article? id=pde2008_S000278.

Brunnermeier, Markus K., Alp Simsek, and Wei Xiong. 2012. "A Welfare Criterion for Models with Distorted Beliefs." Working Paper. Available at http://www. economics.harvard. edu/faculty/simsek/files/welfare8_a.pdf.

Burnside, Craig, Martin Eichenbaum, and Sergio Rebelo. 2011. "Understanding Booms and Busts in Housing Markets." Working Paper No. 16734. Cambridge, MA: National Bureau of Economic Research.

Carter, Susan B., Scott S. Gartner, Michael R. Haines, Alan L. Olmstead, Richard Sutch, and Gavin Wright. 2006. Historical Statistics of the United States: Millennial Edition. Cambridge: Cambridge University Press.

Cheng, Ing-Haw, Sahil Raina, and Wei Xiong. 2012. "Wall Street and the Housing Bubble: Bad Incentives, Bad Models, or Bad Luck?" Princeton University Working Paper.

Cochrane, John H. 2005. Asset Pricing, revised edition. Princeton, NJ: Princeton University Press.

Cordell, Larry, Yilin Huang, and Meredith Williams. 2011. "Collateral Damage: Sizing and Assessing the Subprime CDO Crisis." Federal Reserve Bank of Philadelphia Working Paper. Available at http://www.philadelphiafed.org/research-and-data/ publications/working-papers/2011/wp11-30.pdf.

Coval, Joshua D., Jakub W. Jurek, and Erik Stafford. 2009. "The Economics of Structured Finance." Journal of Economic Perspectives 23(1): 3-25.

Dang, Tri V., Gary Gorton, and Bengt Holmström. 2010. "Financial Crises and the Optimality of Debt for Liquidity Provision." Yale School of Management Working Paper.

Dokko, Jane, Brian Doyle, Michael T. Kiley, Jinill Kim, Shane Sherlund, Jae Sim, and Skander Van den Heuvel. 2009. "Monetary Policy and the Housing Bubble." Board of Governors of the Federal Reserve System, Finance and Economics Discussion Series Papers, No. 2009-49. Washington, DC.

Eakes, Martin. 2007. "Evolution of an Economic Crisis? The Subprime Lending Disaster and the Threat to the Broader Economy." Testimony before Joint Economic 
Committee, September 19, 2007. Available at http://www.responsiblelending.org/ mortgage-lending/policy-legislation/congress/senate-sept-07-final.pdf.

Elul, Ronel. 1997. "Financial Innovation, Precautionary Saving and the Risk-Free Rate." Journal of Mathematical Economics 27(1): 113-131.

Erel, Isil, Taylor D. Nadauld, and René M. Stulz. 2011. "Why Did U.S. Banks Invest in Highly-Rated Securitization Tranches?" Working Paper No. 17269. Cambridge, MA: National Bureau of Economic Research.

Fahlenbrach, Rudiger, and Rene M. Stulz. 2011. "Bank CEO Incentives and the Credit Crisis." Journal of Financial Economics 99(1): 11-26.

Favilukis, Jack, Sydney C. Ludvigson, and Stijn Van Nieuwerburgh. 2010. "The Macroeconomic Effects of Housing Wealth, Housing Finance, and Limited Risk-Sharing in General Equilibrium.” Working Paper No. 15988. Cambridge, MA: National Bureau of Economic Research.

Financial Crisis Inquiry Commission. 2010. "Credit Ratings And the Financial Crisis." Preliminary Staff Report, June 2, 2010. Available at http://fcic-static.law.stanford. edu/cdn_media/fcic-reports/2010-0602-Credit-Ratings.pdf.

Financial Crisis Inquiry Commission. 2011. The Financial Crisis Inquiry Report: Final Report of the National Commission on the Causes of the Financial and Economic Crisis in the United States. New York: Public Affairs.

Fishbein, Allen J. 2006. "Calculated Risk: Assessing Non-Traditional Mortgage Products." Testimony before the Subcommittee on Housing \& Transportation and the Subcommittee on Economic Policy; Senate Committee on Banking, Housing, and Urban Affairs; September 20, 2006. Available at http:// banking. senate. gov/public/index . cfm?Fuseaction=Hearings . Hearing\&Hearing ID $=$ f70279b0 $-1372-4075-a 740-9 a 1 a e b 7 b d c 3 e$.

Flanagan, Christopher, Ting Ko, Seva Levitski, Chris Muth, and Amy Sze. 2006a. "February 2006 House Price Appreciation Update." J.P. Morgan Global Credit Research, April 11, 2006.

Flanagan, Christopher, Ting Ko, Seva Levitski, Chris Muth, and Amy Sze. 2006b. "House Price Appreciation Update." JP Morgan Global Credit Research, various dates. 
Foote, Christopher L., Kristopher Gerardi, Lorenz Goette, and Paul S. Willen. 2008. "Just the Facts: An Initial Analysis of Subprime's Role in the Housing Crisis." Journal of Housing Economics 17(4): 291-305.

Foote, Christopher L., Kristopher Gerardi, and Paul S. Willen. 2008. "Negative Equity and Foreclosure: Theory and Evidence." The Journal of Urban Economics 64(2): 234-245.

Fuster, Andreas, David Laibson, and Brock Mendel. 2010. "Natural Expectations and Macroeconomic Fluctuations." Journal of Economic Perspectives 24(4): 67-84.

Garber, Peter M. 2000. Famous First Bubbles: The Fundamentals of Early Manias. Cambridge, MA: MIT Press.

Geanakoplos, John. 2009. "The Leverage Cycle." In NBER Macroeconomics Annual 2009, eds. Daron Acemoglu, Kenneth Rogoff, and Michael Woodford, 1-65. Chicago, IL: University of Chicago Press.

Gennaioli, Nicola, and Andrei Shleifer. 2010. "What Comes to Mind." Quarterly Journal of Economics 125(4): 1399-1433.

Gennaioli, Nicola, Andrei Shleifer, and Robert Vishny. 2011 [online proof]. "Neglected Risks, Financial Innovation, and Financial Fragility." Journal of Financial Economics.

Gerardi, Kristopher, Andreas Lehnert, Shane M. Sherlund, and Paul S. Willen. 2008. "Making Sense of the Subprime Crisis." Brookings Papers on Economic Activity 2: 69-145.

Gerardi, Kristopher S., Christopher L. Foote, and Paul S. Willen. 2011. "Reasonable People Did Disagree: Optimism and Pessimism about the U.S. Housing Market Before the Crash." In Reinventing the American Mortgage System: Rethink, Recover, Rebuild., eds. Marvin Smith and Susan M. Wachter, 36-78. Philadelphia: University of Pennsylvania Press.

Gerardi, Kristopher S., Harvey S. Rosen, and Paul S. Willen. 2010. "The Impact of Deregulation and Financial Innovation on Consumers: The Case of the Mortgage Market." Journal of Finance 65(1): 333-360.

Gerth, Jeff. 1981. "Savings Regulators End Mortgage Curb." The New York Times, April 24.

Ghent, Andrea, Ruben Hernandez-Murillo, and Michael T. Owyang. 2012. "Did Affordable Housing Legislation Contribute to the Subprime Securities Boom?" Federal Reserve Bank of St. Louis Working Paper 2012-005A. Available at http://research.stlouisfed.org/ wp/2012/2012-005.pdf. 
Glaeser, Edward L., Joshua D. Gottlieb, and Joseph Gyourko. 2010. "Can Cheap Credit Explain the Housing Boom?" Working Paper No. 16230. Cambridge, MA: National Bureau of Economic Research.

Gorton, Gary. 2010. Slapped by the Invisible Hand: The Panic of 200\%. New York: Oxford University Press.

Grossman, Sanford J., and Oliver D. Hart. 1980. "Disclosure Laws and Takeover Bids." Journal of Finance 35(2): 323-334.

Guttentag, Jack. 1984. "Recent Changes in the Primary Home Mortgage Market." Housing Finance Review 3: 221-254.

Harrigan, Susan. 1981. "Wachovia Has Other Bankers Taking Notice." Wall Street Journal, April 27.

Herzog, John P., and James S. Earley. 1970. "Home Mortgage Delinquency and Foreclosure." Cambridge, MA: National Bureau of Economic Research. Available at http://www.nber . org/chapters/c3293.pdf.

Hough, Susan, and Lucile Jones. 2002. "Earthquakes Don't Kill People, Buildings Do." San Francisco Chronicle Op-Ed Commentary, December 4, 2002. Available at http://pasadena.wr.usgs.gov/office/hough/oped-sf.html.

Inside Mortgage Finance Publications. 2008. 2008 Mortgage Market Statistical Annual. Bethesda, MD.

Inside Mortgage Finance Publications. 2011. 2011 Mortgage Market Statistical Annual. Bethesda, MD.

Jiang, Wei, Ashlyn Nelson, and Edward Vytlacil. 2011. "Liar's Loan? Effects of Origination Channel and Information Falsification on Mortgage Delinquency." Columbia University Graduate School of Business Working Paper. Available at http://www.columbia.edu/ $\sim$ wj2006/liars_loan.pdf.

Jozoff, Matthew, John Sim, Abhishek Mistry, Asif Sheikh, Robert Saltarelli, and Kaustub Samant. 2012. "MBS Credit Monthly, February." JP Morgan SPG Research, February 10, 2012.

Kashyap, Anil K. 2010. "Lessons from the Financial Crisis for Risk Management." Paper Prepared for the Financial Crisis Inquiry Commission, Feburary 27, 2010. Available 
at http://faculty.chicagobooth.edu/anil.kashyap/research/papers/lesson_for_ fcic.pdf.

Khandani, Amir E., Andrew W. Lo, and Robert C. Merton. 2009. "Systemic Risk and the Refinancing Ratchet Effect." Working Paper No. 15362. Cambridge, MA: National Bureau of Economic Research.

Klaman, Saul B. 1959. "The Postwar Rise of Mortgage Companies." Bureau of Economic Research Occasional Paper No. 60. New York: National Bureau of Economic Research.

Lewis, Michael. 2010. The Big Short: Inside the Doomsday Machine. New York: W.W. Norton \& Company.

Liu, David. 2005. "Credit Performance of Option ARMs." U.S. Securitized Products Strategy Group Slide Deck, August 15, 2005.

MacKay, Charles. 2003 [1841]. Extraordinary Popular Delusions and the Madness of Crowds. Hampshire, England: Harriman House.

Mago, Akhil, and Sihan Shu. 2005. "HEL Bond Profile Across HPA Scenarios." U.S. ABS Weekly Outlook, Lehman Brothers Fixed-Income Research, August 15, 2005.

McCullough, David. 1977. The Path Between the Seas: The Creation of the Panama Canal, 1870-1914. New York: Simon \& Schuster.

Merton, Robert C. 1969. "Lifetime Portfolio Selection Under Uncertainty: The ContinuousTime Case." Review of Economics and Statistics 51(3): 247-257.

Mian, Atif, and Amir Sufi. 2009. "The Consequences of Mortgage Credit Expansion: Evidence from the U.S. Mortgage Default Crisis." Quarterly Journal of Economics 124(4): 1449-1496.

Miao, Jianjun, and Pengfei Wang. 2011. "Bubbles and Credit Constraints." Boston University Working Paper. Available at http://people.bu.edu/miaoj/Bubble.pdf.

Morgenson, Gretchen, and Joshua Rosner. 2011. Reckless Endangerment: How Outsized Ambition, Greed, and Corruption Led to Economic Armageddon. New York: Times Books.

Moulten, Shawn. 2010. "The 1992 GSE Act and Loan Application Outcomes." University of Notre Dame Working Paper.

Muolo, Paul, and Mathew Padilla. 2010. Chain of Blame: How Wall Street Caused the Mortgage and Credit Crisis. New York: John Wiley \& Sons. 
National Mortgage News. 2005. "Subprime Growth Fueled $\$ 750$ Billion in 3rd-Quarter Originations." October 24, 2005.

Nocera, Joe. 2011. "Inquiry is Missing Bottom Line." New York Times, page B1. January 29, 2011. Available at http://www.nytimes.com/2011/01/29/business/29nocera.html.

Porter, David, and Vernon L. Smith. 2008. "Price Bubbles." In Handbook of Experimental Economics Results, eds. Charles R. Plott and Vernon L. Smith, vol. 1, 247-255. Amsterdam: Elsevier.

Rajan, Raghuram G. 2010. Fault Lines: How Hidden Fractures Still Threaten the World Economy. Princeton, NJ: Princeton University Press.

Ranieri, Lewis S. 1996. "The Origins of Securitization, Sources of its Growth, and its Future Potential." In A Primer on Securitization, ed. Leon T. Kendall and Michael J. Fishman, 31-44. Cambridge, MA: The MIT Press.

Salmon, Felix. 2009. "Recipe for Disaster: The Formula that Killed Wall Street." Wired Magazine Available at http://www.wired.com/techbiz/it/magazine/17-03/wp_ quant? currentPage=all.

Savastano, Albert. 2005. "Basic Report: Golden West Financial." Janney Montgomery Scott, January 13, 2005.

Shiller, Robert J. 2005. Irrational Exuberance, second edition. Princeton, NJ: Princeton University Press.

Sichelman, Lew. 1990. "Fannie Mae Sets 30 Percent Down on Low-Doc Loan." Chicago Tribune, July 14, 1990. Available at http://articles.chicagotribune.com/1990-07-14/ news/9002270602_1_low-doc-loan-no-doc-loans-maximum-fha-loan.

Simon, Ruth. 2005. "Mortgage Lenders Loosen Standards-Despite Growing Concerns, Banks Keep Relaxing Credit-Score, Income and Debt-Loan Rules." Wall Street Journal, page D1. July 26, 2005.

Simon, Ruth, and James R. Hagerty. 2005. "How American Lenders Shelter Themselves." Wall Street Journal, page C1. September 22, 2005.

Simsek, Alp. 2012. "Belief Disagreements and Collateral Constraints." Harvard University Working Paper. Available at http://www.economics.harvard.edu/faculty/simsek/ files/simsekBeliefDisagreementsCollateralConstraints7_EMArevision.pdf. 
Smith, Vernon L., Gerry L. Suchanek, and Arlington W. Williams. 1988. "Bubbles, Crashes, and Endogenous Expectations in Experimental Spot Asset Markets." Econometrica 56(5): 1119-1151.

Sorkin, Andrew Ross. 2010. Too Big to Fail: The Inside Story of How Wall Street and Washington Fought to Save the Financial System-and Themselves. New York: Penguin.

Stahl, David. 1996. "A COFI break." Mortgage Banking November 1.

Tett, Gillian. 2009. Fool's Gold: How Unrestrained Greed Corrupted a Dream, Shattered Global Markets and Unleashed a Catastrophe. New York: Little, Brown.

Thomas, Jason, and Robert Van Order. 2011. "A Closer Look at Fannie Mae and Freddie Mac: What We Know, What We Think We Know and What We Don't Know." George Washington University Department of Finance Draft Paper (March).

Warren, Elizabeth. 2010. "Priorities for the New Consumer Financial Protection Bureau." Speech before the Consumer Federation of America Financial Services Conference, December 2, 2010. Available at http://www.treasury.gov/press-center/press-releases/ Pages/tg987. aspx.

Warren, Elizabeth, and Amelia W. Tyagi. 2004. The Two Income Trap: Why Middle-Class Parents Are Going Broke. New York: Basic Books.

Zimmerman, Thomas. 2005. "Subprime Home Equities: Its (Almost) All About Home Prices." UBS U.S. Securitized Products Strategy Group, Conference Call Slide Presentation, September 26, 2005.

Zuckerman, Gregory. 2010. The Greatest Trade Ever: The Behind-the-Scenes Story of How John Paulson Defied Wall Street and Made Financial History. New York: Crown Business. 


\section{Conventional Wisdom}

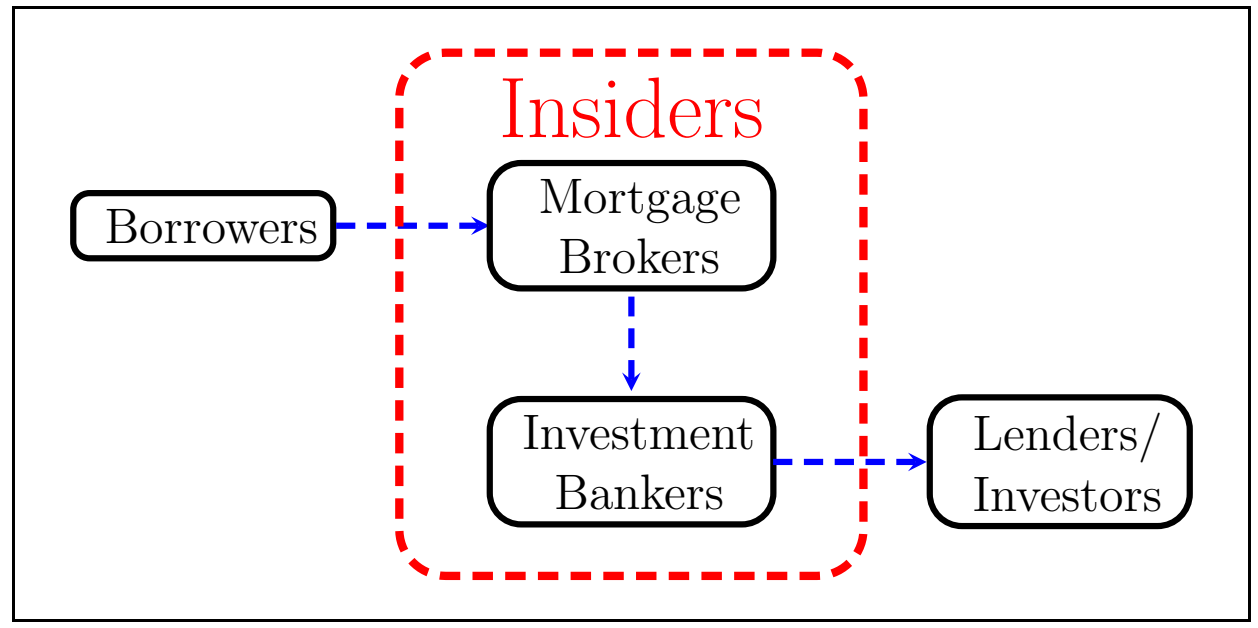

\section{Bubble Theory}

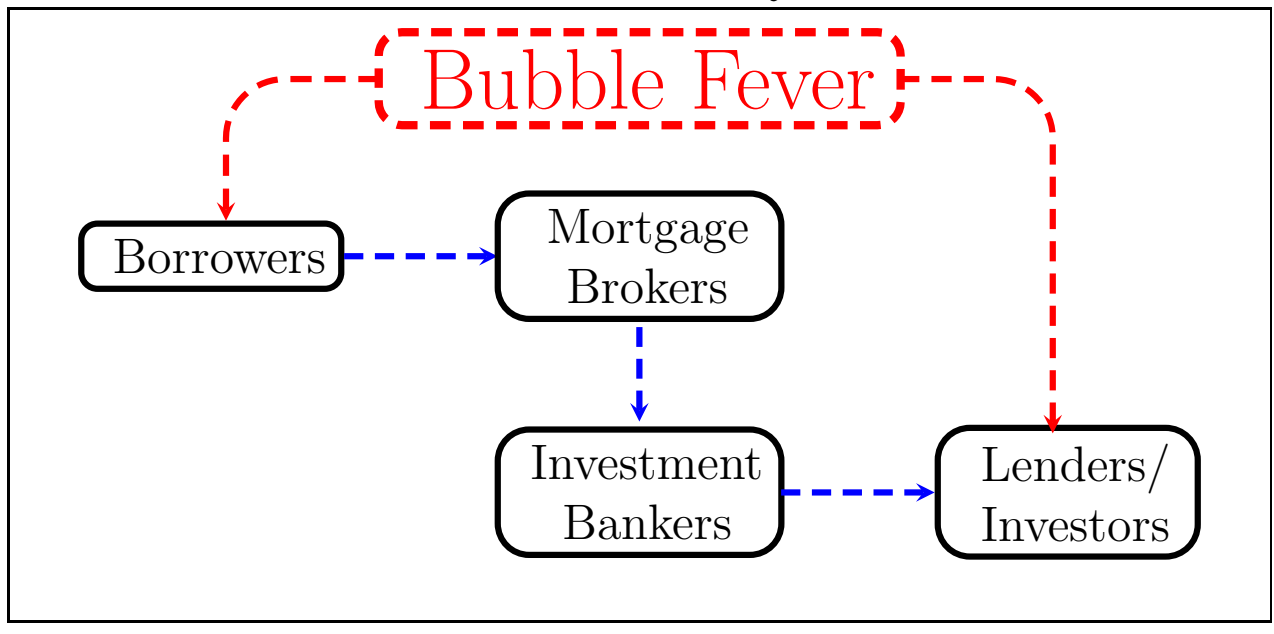

Figure 1. Alternative Theories of the Foreclosure Crisis. The top panel illustrates the conventional wisdom about the financial crisis: mortgage industry insiders (mortgage brokers and investment bankers) took advantage of outsiders (borrowers and investors). Brokers cheated borrowers by extending them "exploding" mortgages, which become unaffordable when their interest rates reset. Investment bankers took advantage of investors by packaging mortgages in complex securities, leaving investors unable to discern the "toxic" nature of the mortgages involved. The lower panel presents the bubble view of the crisis: both borrowers and lenders believed that house prices would continue rising. Borrowers were eager to purchase homes and investors wanted more exposure to the housing market. The securitization process merely facilitated these transactions. 

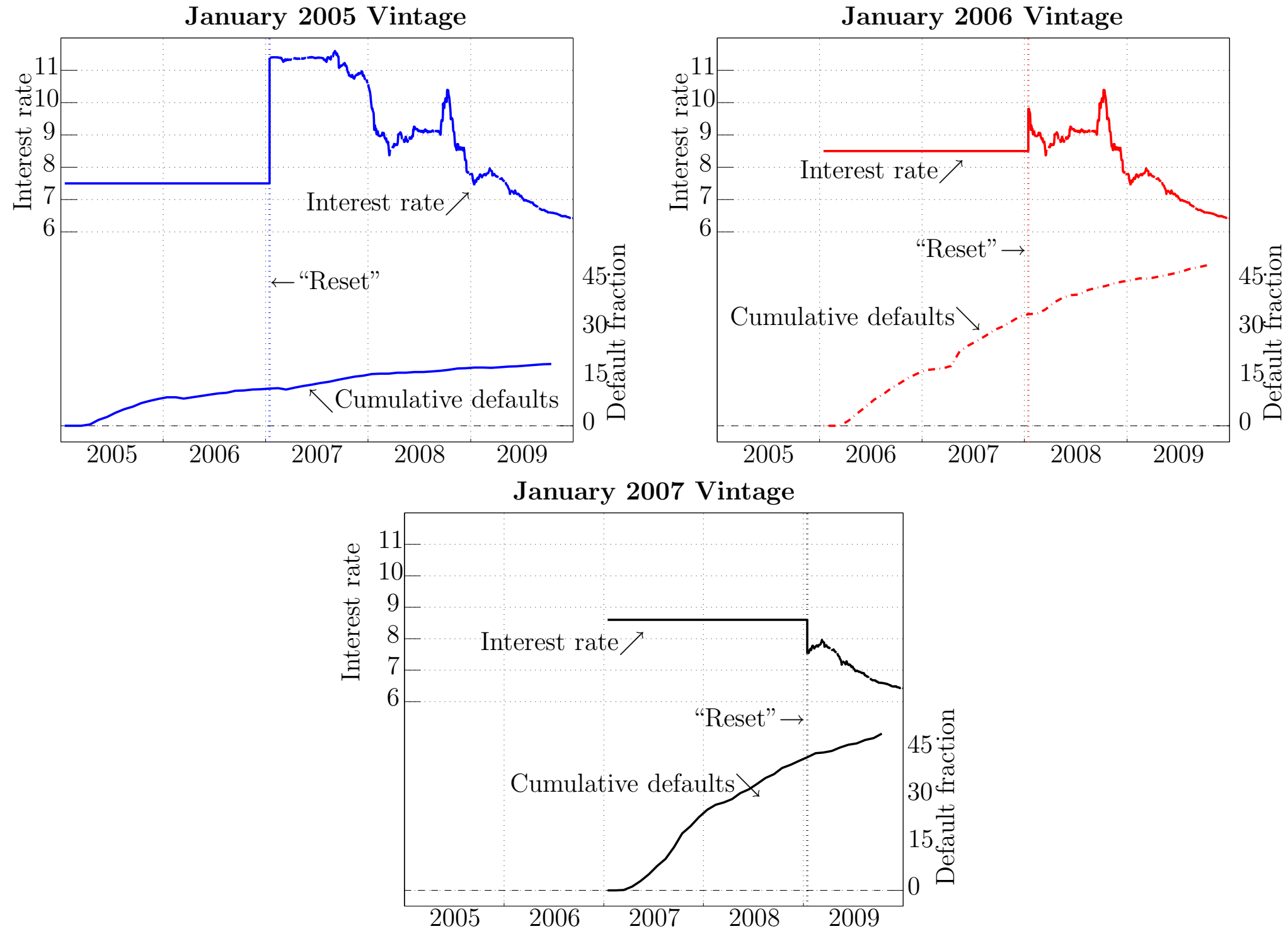

Figure 2. Interest Rates and Cumulative Defaults for Three Vintages of Subprime $2 / 28$ Mortgages. These graphs illustrate that defaults on subprime $2 / 28$ mortgages did not generally spike after two years when their interest rates reset. In fact, the worst-performing vintage in the chart, the January 2007 loans, did not experience an interest rate reset, because interest rates had fallen significantly by January 2009 . Source: authors' calculations using data from Lender Processing Services, Inc. 
FICO $<620$
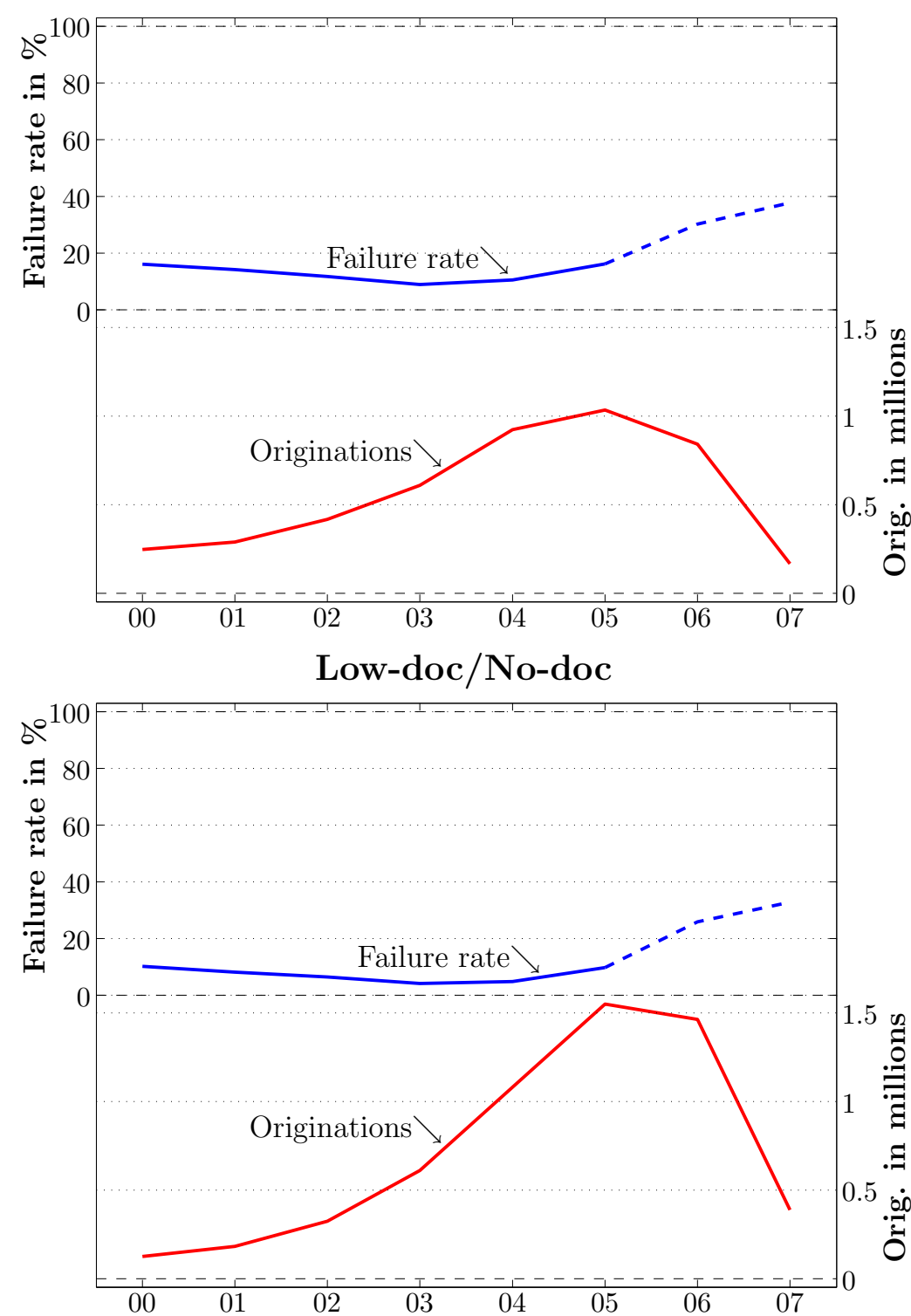

$\mathbf{L T V}=100$

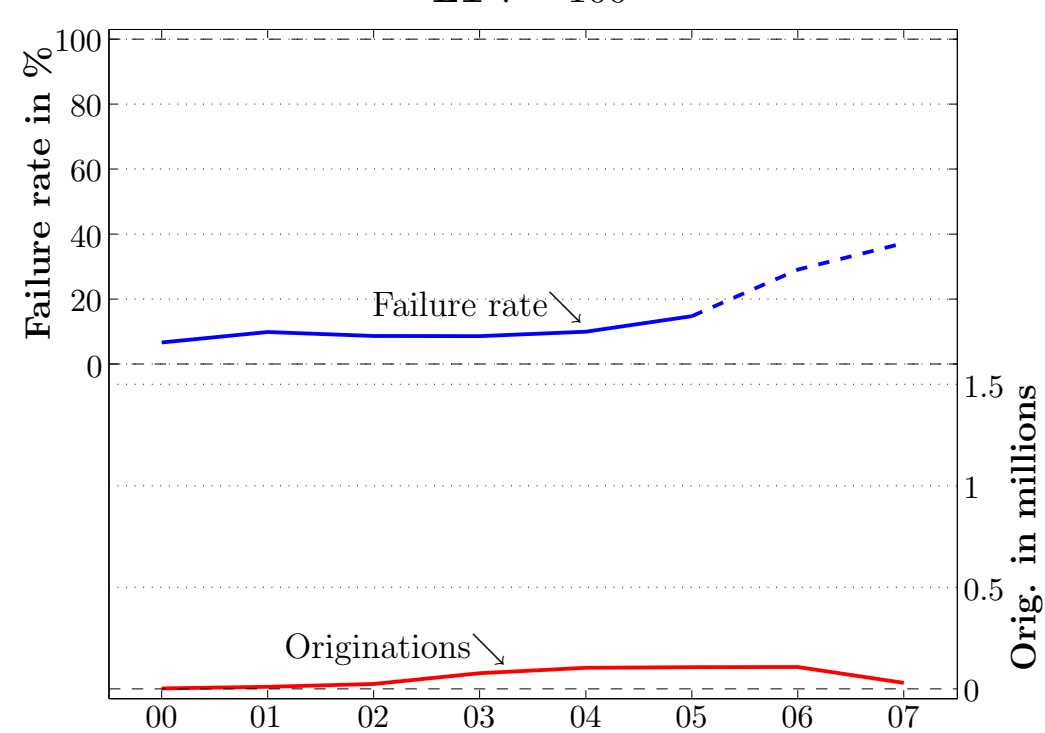

Negativ-Amort + LTV $>90+$ Low-Doc/No-Doc

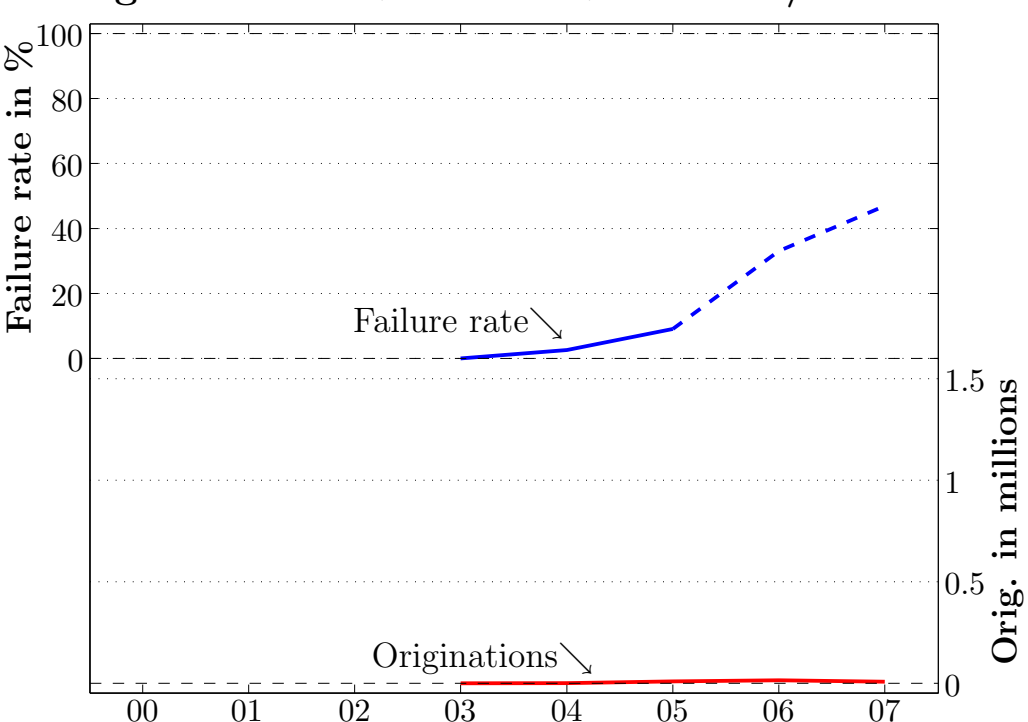

Figure 3. Failure Rates and Originations for Selected Nonprime Mortgages. Failure rates are graphed by year of origination, and correspond to the fraction of mortgages that are at least 60-days delinquent two years after origination. The dashed line denotes years after 2005. Source: authors' calculations using data from CoreLogic, Inc. (originally LoanPerformance). The sample includes all subprime and Alt-A loans in the CoreLogic database. 
Washington Mutual is proud to offer the "More House for Your Money" loan."

"not affitiated with "Less House for Your Money" loan you nay find elsewhere.

\section{Glanes ower cur adiustable rate mort tagage} statement, and chantives are you't feet like momenthy payment uptiusts not conly make it

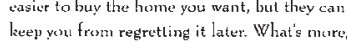
Heré's a low lifetime cap and maresin. After Ill, when it comles tre home buying, uptions

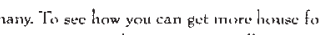

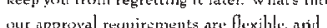
Washington Mutual

\section{CALL 1-888-WAMU-LEND (1-888-926-8536)}

醇

\section{Better Mortgages for Better Family Living!}

The Apple Mortgage Program:

- Superior rates, points and terms which you can lock in - Professionallsm. Experienced and dedicated, our - Professionallsm. Experienced and dedicated,
mortgage representatives are tops in the field.

- Speed. Approval within one to four weeks on most applications.

- A variety of fixed and adjustable rate loan
programs, including convertible 1-year ARM's.

- No Income Verification Loans at no

additional charge.

- Reduced points for CD depositors.

- Additional savings for Apple Bank Family Member

- Buyups and Buydowns available.

- Home Equity Loans available.
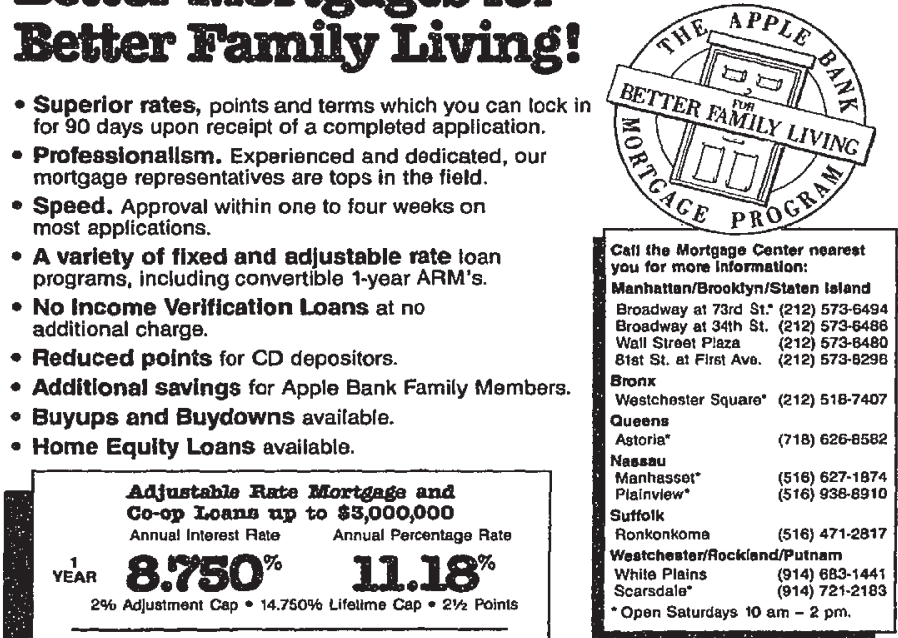

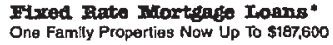

$\mathbf{9 . 5 0 0 \%} 9.94 \%$

9.875\% $10.18^{\%}$

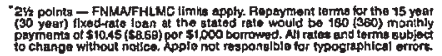

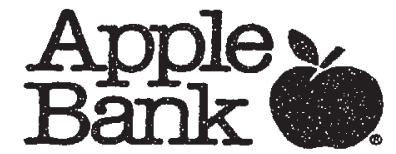

for Savings

We're good for you.

Iocatlong throushout greatex Now York

\begin{tabular}{c} 
Est. 1863 \\
Member Foic \\
\hline
\end{tabular}

Figure 4. Evidence of Option ARMs and Low Documentation Loans Before the Housing Boom. The ad on the left, from The New York Times on July 26, 1998, is for a payment-option ARM. The ad on the right, from The New York Times on June 25, 1989, is for a low-documentation loan ("no income verification"). These ads illustrate that many of the mortgages used extensively during the boom had been available many years previously.

Source: New York Times. 

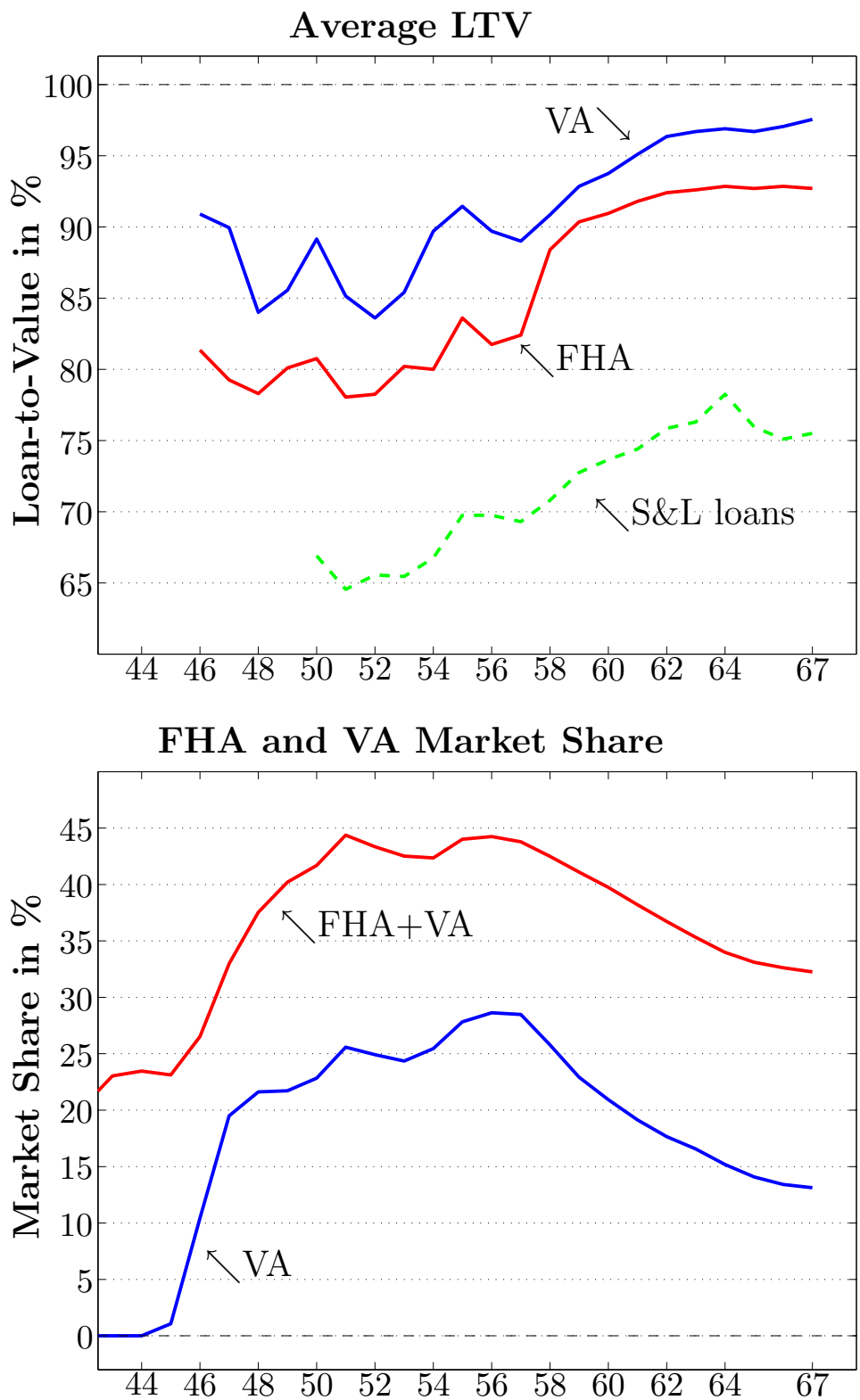

Figure 5. FHA and VA Loan Programs in the Immediate Postwar Era. In response to changes in government policies, mortgages with no downpayments were prevalent in the 1950s and 1960s, decades before the mortgage crisis began.

Source: LTVs from Herzog and Earley (1970) and Market shares from series Dc948 (FHA), DC949 (VA) and Dc934 (Total) from Carter et al. (2006). 


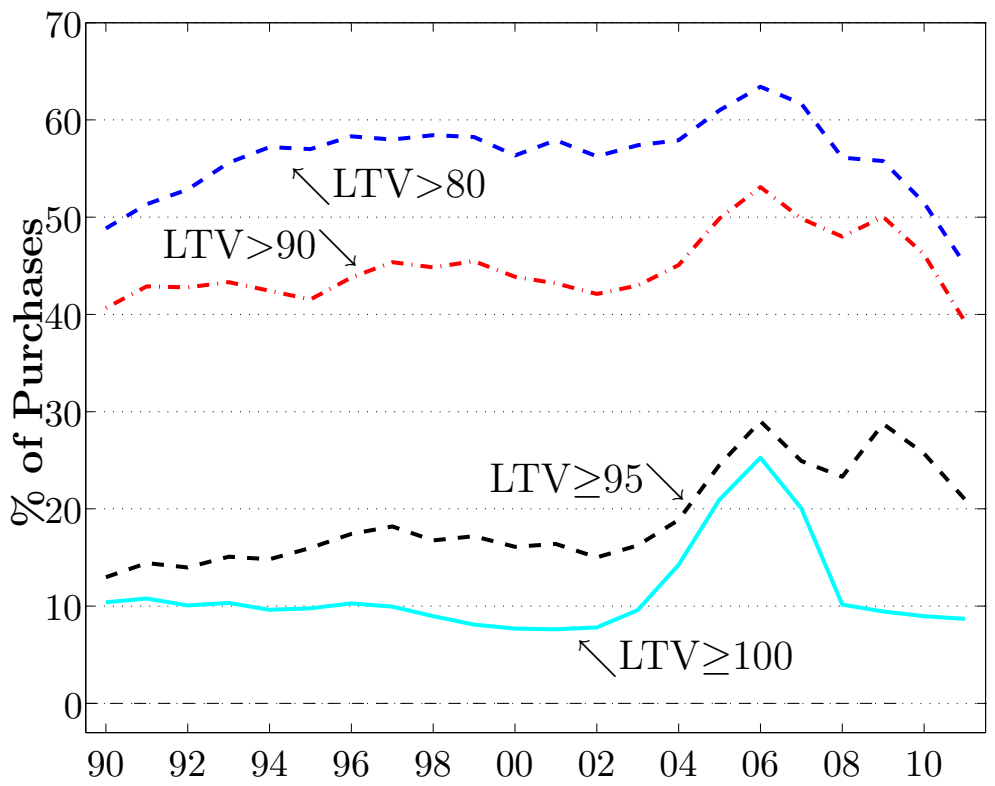

Figure 6. Distribution of Combined loan-to-Value (LTV) Ratios on Home Purchases in MASSACHUSETTS: 1990-2011. The top line shows that a majority of home buyers in Massachusetts put down less than 20 percent in most years after 1990. These statistics include all mortgages taken out at the time of purchase and encompass cash buyers.

Source: Warren Group collection of data from Massachusetts deed registries and authors' calculations. 
The Growing Role of Mortgage Companies

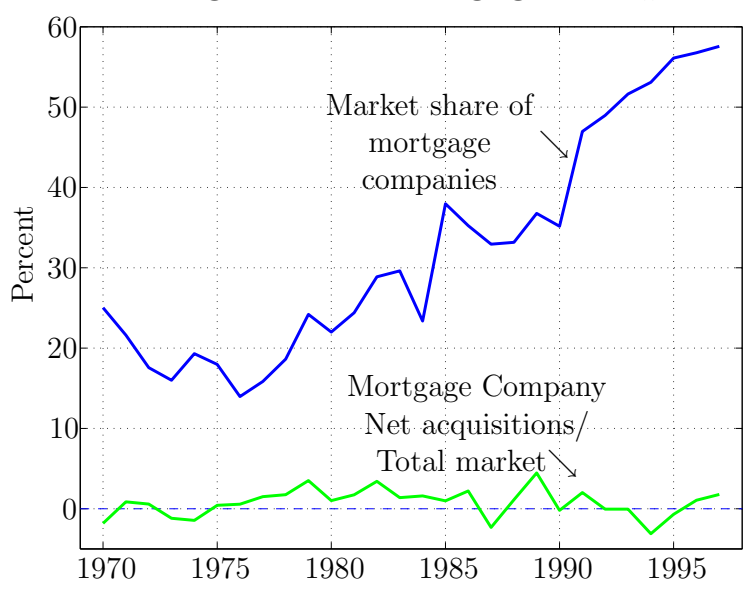

Evolution of S\&Ls

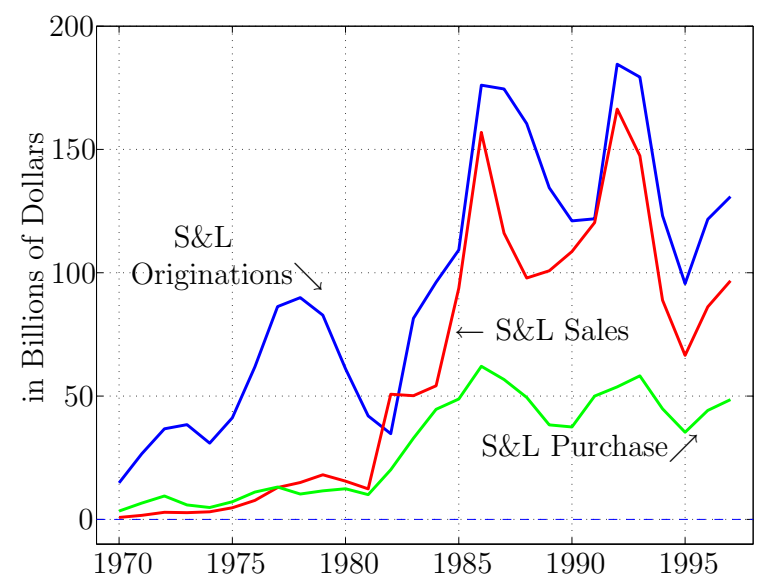

Decline of the "Originate-to-Hold" Model

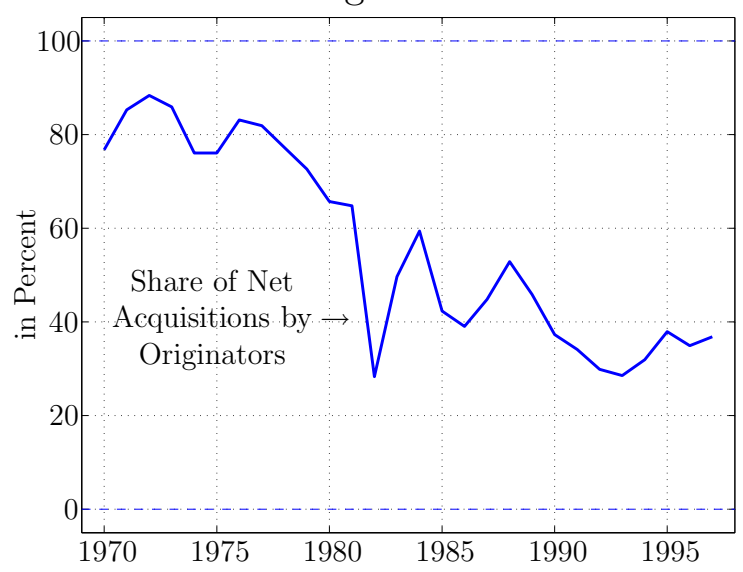

Figure 7. Mortgage Statistics for Mortgage Companies and Savings and Loans: 1970-1997. The upper left panel shows that the market share of mortgage companies, a type of mortgage bank that originates mortgages for sale to outside investors, began to grow rapidly in the late 1970s. The upper right panel shows that after 1980, S\&Ls sold most of the mortgages they originated, becoming much like mortgage companies. The bottom panel shows that the decline of the "originate-to-hold" model started long before the recent housing boom.

Source: Carter et al. (2006). 


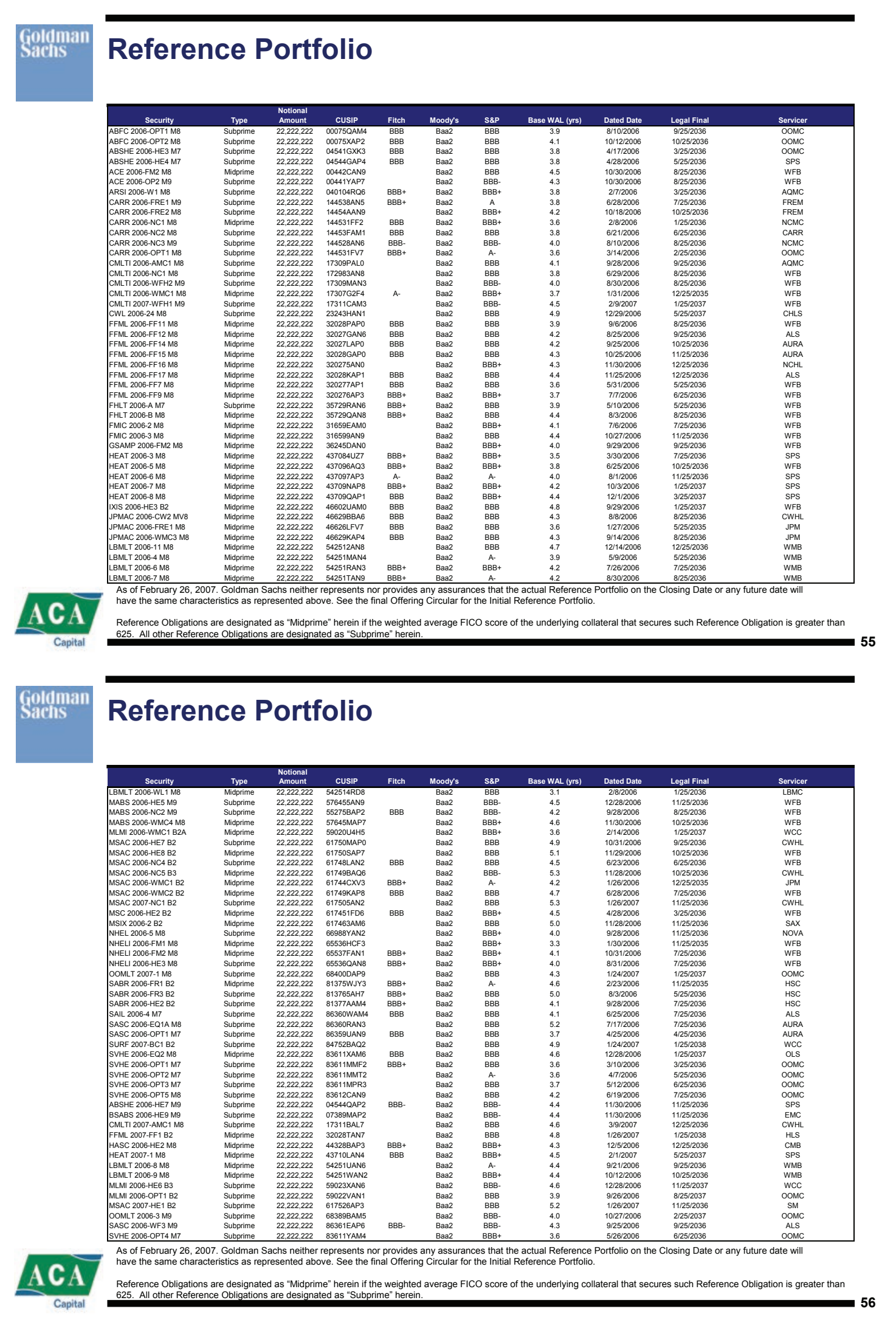

Figure 8. The Reference Portfolio of the Abacus Deal. These two tables present the bonds included in the Goldman Sachs Abacus deal. They illustrate that potential investors in this deal had all the information they needed to model the underlying cash flows on the mortgages involved. 


\section{Vintage MBSs}

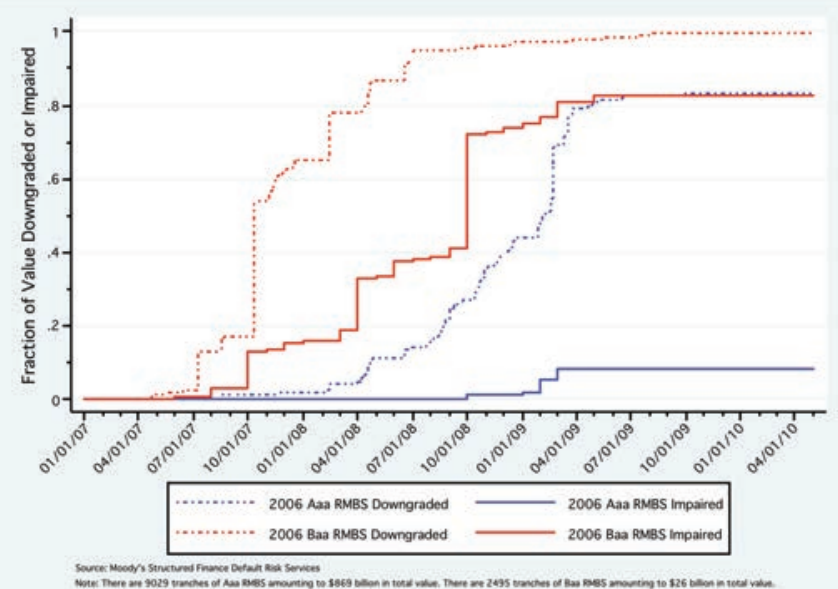

2007 Vintage MBSs

\section{Vintage CDOs}

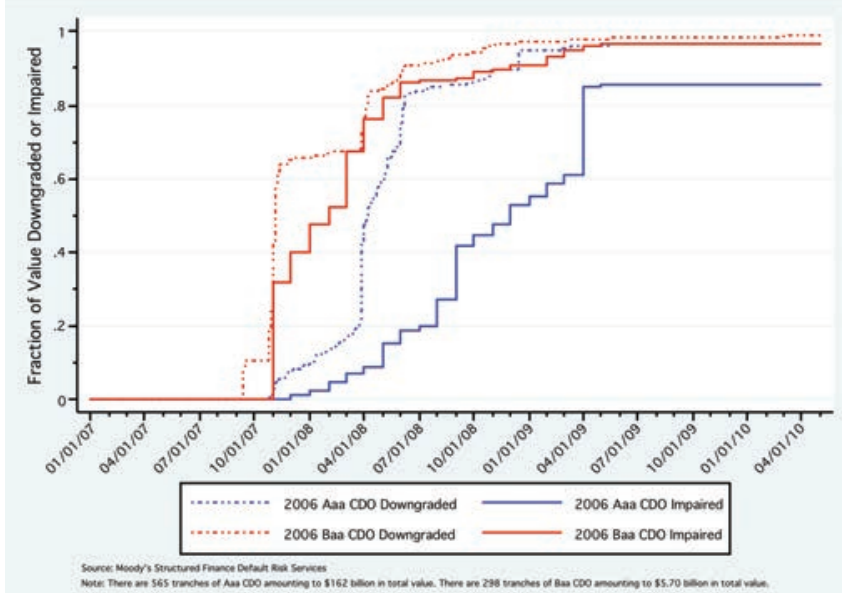

2007 Vintage CDOs

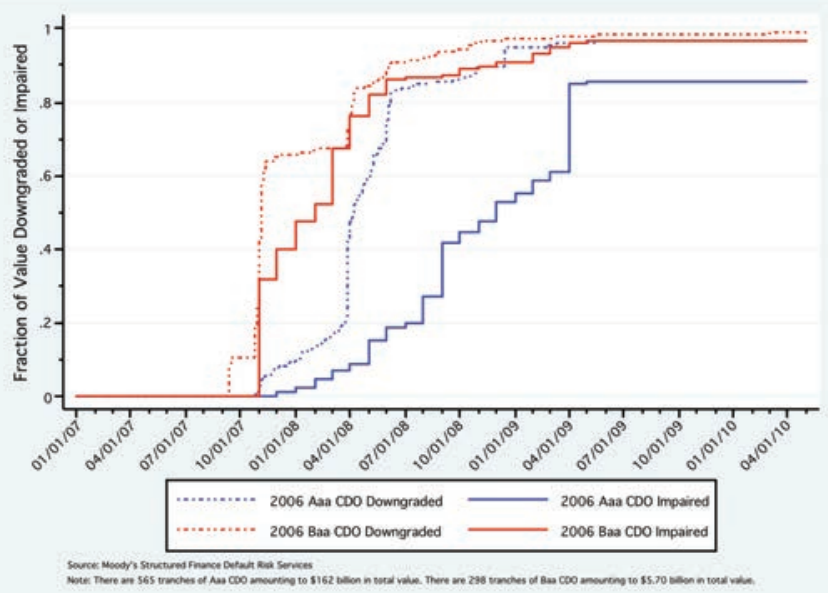

Figure 9. Downgrades and Impairments Among Mortgage-Backed Securities (MBS) and Collateralized Debt Obligations (CDOs). The two panels on the left show that among private-label MBS, lower-rated tranches suffered massive losses. However, while a large fraction of AAA-rated tranches were downgraded, the vast majority of these tranches paid off, as few of them suffered actual impairments. The two panels on the right show that the same is not true for CDOs. Because these bonds tended to be backed by the lower-rated tranches of private-label MBS, both the AAA-rated and the lower-rated tranches of CDOs suffered significant impairments.

Source: Tables 12, 13, 17 and 18 in Financial Crisis Inquiry Commission (2010). 


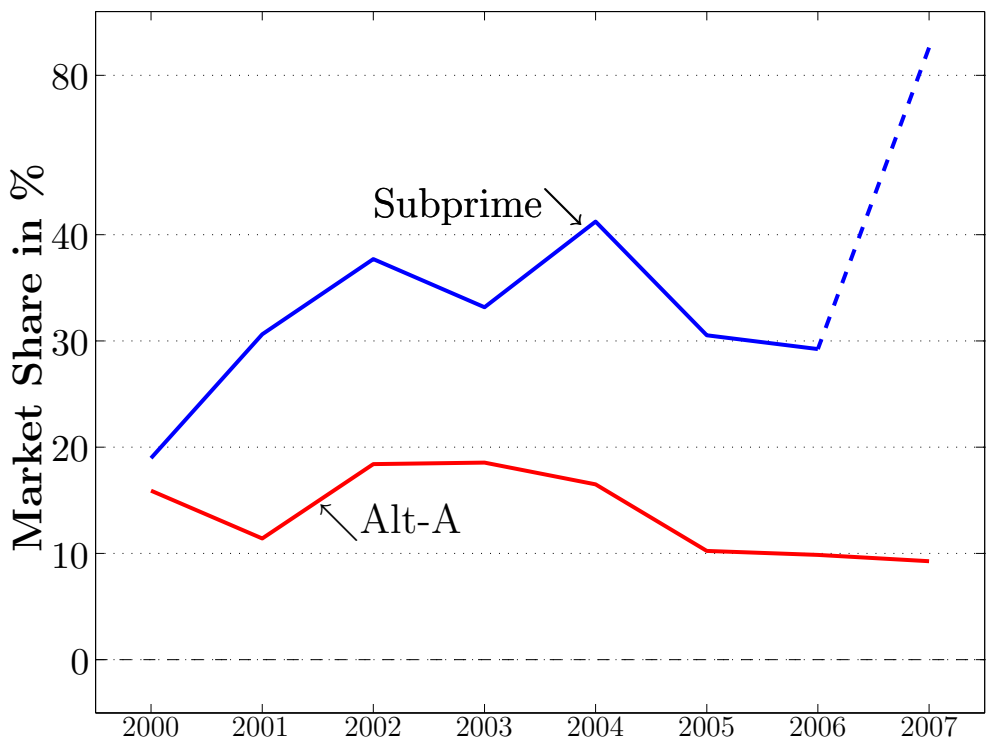

Figure 10. GSE Investments in SubPrime And Alt-A Residential MBS: 2000-2007. This graph shows that the government-sponsored housing enterprises, Fannie Mae and Freddie Mac, were significant purchasers of highly rated tranches of subprime and Alt-A securities during the housing boom. As a share of the overall subprime market, GSE purchases rose sharply in 2007 (note the change in vertical scale between 40 and 80 percent). This increase in share came about even though the absolute amount of subprime securities purchased by the GSEs declined in 2007; the overall subprime market contracted much more in percentage terms than GSE purchases did.

Source: Thomas and Van Order (2011). 
Payment changes and default

\begin{tabular}{|c|c|c|c|c|c|c|}
\hline & 2007 & 2008 & 2009 & 2010 & All \\
\hline \multicolumn{2}{|l|}{ FRM share } & $38 \%$ & $48 \%$ & $62 \%$ & $74 \%$ & $59 \%$ \\
\hline \multicolumn{7}{|c|}{ Prior to delinquency spell that led to foreclosure... } \\
\hline \multirow{4}{*}{$\begin{array}{l}\% \text { of loans } \\
\text { with... }\end{array}$} & Reset & $18 \%$ & $20 \%$ & $18 \%$ & $11 \%$ & $17 \%$ \\
\hline & Payment increase & $12 \%$ & $17 \%$ & $11 \%$ & $9 \%$ & $12 \%$ \\
\hline & Payment reduction & $0 \%$ & $0 \%$ & $4 \%$ & $8 \%$ & $4 \%$ \\
\hline & No change since orig. & $88 \%$ & $82 \%$ & $85 \%$ & $83 \%$ & $84 \%$ \\
\hline \multicolumn{2}{|c|}{ Private Label } & $68 \%$ & $54 \%$ & $37 \%$ & $23 \%$ & $41 \%$ \\
\hline \multicolumn{2}{|c|}{ \# obs in thous. } & 374 & 641 & 874 & 756 & 2,646 \\
\hline
\end{tabular}

\section{Relative Performance of Subprime ARMs and FRMs}

\begin{tabular}{|c|c|c|c|c|c|c|c|c|}
\hline & \multicolumn{2}{|c|}{ All Subprime } & \multicolumn{3}{|c|}{ Subprime FRMs } & \multicolumn{3}{|c|}{ Subprime $2 / 28 \mathrm{~s}$} \\
\hline & $\begin{array}{l}\text { \# of orig. } \\
\text { in thou. }\end{array}$ & $P($ default $)$ & $\begin{array}{c}\text { \# of orig. } \\
\text { in thou. }\end{array}$ & $\begin{array}{l}\text { Share } \\
\text { in } \%\end{array}$ & $P($ default $)$ & $\begin{array}{c}\text { \# of orig. } \\
\text { in thou. }\end{array}$ & $\begin{array}{c}\text { Share } \\
\text { in } \%\end{array}$ & $P($ default $)$ \\
\hline 2005 & 529 & 41.9 & 198 & 37.3 & 37.1 & 332 & 62.7 & 44.8 \\
\hline 2006 & 504 & 55.9 & 258 & 51.2 & 50.7 & 246 & 48.8 & 61.4 \\
\hline 2007 & 246 & 55.9 & 208 & 84.5 & 53.8 & 38 & 15.5 & 66.8 \\
\hline Total & 1278 & 50.1 & 663 & 51.9 & 47.6 & 615 & 48.1 & 52.8 \\
\hline
\end{tabular}

Table 1. Payment Changes and Defaults among Various Mortgage Types. The top table shows that a small minority of borrowers who eventually lost their homes to foreclosure experienced a payment increase before they first became delinquent. Payment increases preceded initial delinquency for only 12 percent of borrowers. Eighty-four percent of borrowers who eventually lost their homes were making the same payment at the time of initial delinquency as when they first took out their loans. The bottom table shows that 52.8 percent of subprime borrowers with adjustable-rate $2 / 28$ mortgages originated from 2005 to 2007 defaulted. The comparable percentage for fixed-rate mortgages is 47.6 percent - only a few percentage points lower.

Source: authors' calculations using data from Lender Processing Services, Inc. 


\begin{tabular}{llcc} 
Name & Scenario & Probability & Cum Loss \\
\hline (1) Aggressive & 11\% HPA over the life of the pool & $15 \%$ & $1.4 \%$ \\
(2) & 8\% HPA for life & $15 \%$ & $3.2 \%$ \\
(3) Base & HPA slows to 5\% by end-2005 & $50 \%$ & $5.6 \%$ \\
(4) Pessimistic & 0\% HPA for the next 3 years 5\% thereafter & $15 \%$ & $11.1 \%$ \\
(5) Meltdown & -5\% for the next 3 years, 5\% thereafter & $5 \%$ & $17.1 \%$
\end{tabular}

Table 2. Conditional Forecasts of Losses on Subprime Investments from Lehman Brothers. This table shows that investors knew that subprime investments would turn sour if housing prices fell. The "meltdown" scenario for housing prices above implies cumulative losses of 17.1 percent on subprime-backed bonds; such losses would be large enough to wipe out all but the highest-rated tranches of most subprime deals. The table also shows that investors placed small probabilities on these adverse price scenarios, a fact that explains why they were so willing to buy these bonds.

Source: "HEL Bond Profile Across HPA Scenarios" from Lehman Brothers: "U.S. ABS Weekly Outlook," August 15, 2005.

\begin{tabular}{ccl} 
Date of & Data from & Title \\
\hline $12 / 8 / 06$ & $10 / 06$ & "More widespread declines with early stabilization signs" \\
$1 / 10 / 07$ & $11 / 06$ & "Continuing declines with stronger stabilization signs" \\
$2 / 6 / 07$ & $12 / 06$ & "Tentative stabilization in HPA" \\
$3 / 12 / 07$ & $1 / 07$ & "Continued stabilization in HPA" \\
$9 / 20 / 07$ & $7 / 07$ & "Near bottom on HPA" \\
$11 / 2 / 07$ & $9 / 07$ & "UGLY! Double digit declines in August and September"
\end{tabular}

Table 3. Views on House Price Appreciation from JPMorgan Analysts. Even as housing prices began to fall from their elevated levels, many analysts believed that prices would soon stabilize. The table provides further evidence that investors were optimistic about house prices during the boom.

Source: Flanagan et al. (2006b). 


\begin{tabular}{llc||clc}
\hline \hline & Institution & $\begin{array}{c}\text { Loss } \\
\text { (\$ billions) }\end{array}$ & & Institution & $\begin{array}{c}\text { Loss } \\
\text { (\$ billions) }\end{array}$ \\
\hline 1 & Citigroup & 42.9 & 11 & Washington Mutual & 9.1 \\
2 & UBS & 38.2 & 12 & Credit Agricole & 8.3 \\
3 & Merrill Lynch & 37.1 & 13 & Lehman Brothers & 8.2 \\
4 & HSBC & 19.5 & 14 & Deutsche Bank & 7.6 \\
5 & IKB Deutsche & 15.9 & 15 & Wachovia & 7.0 \\
6 & Royal Bank of Scotland & 15.2 & 16 & HBOS & 7.0 \\
7 & Bank of America & 15.1 & 17 & Bayerische Landesbank & 6.7 \\
8 & Morgan Stanley & 14.1 & 18 & Fortis & 6.6 \\
9 & JPMorgan Chase & 9.8 & 19 & Canadian Imperial (CIBC) & 6.5 \\
10 & Credit Suisse & 9.6 & 20 & Barclays & 6.3 \\
\hline \hline
\end{tabular}

Table 4. Mortgage-Related Losses to Financial Institutions from the Subprime Crisis, as OF June 18, 2008. The date is chosen prior to the Lehman bankrupcty to avoid contamination from wider financial crisis. This table shows that mortgage industry insiders were the biggest losers from the housing crash, despite the claims of the inside job theory of the crisis.

Source: Bloomberg (http://www.bloomberg.com/apps/news?pid=newsarchive\&sid=a5GaivCMZu_M). 


\begin{tabular}{lcccccc|c}
\hline \hline Entity & Loans & $\begin{array}{c}\text { HELOC } \\
+2 \text { nds }\end{array}$ & $\begin{array}{c}\text { Agency } \\
\text { MBS }\end{array}$ & $\begin{array}{c}\text { Non-Agency } \\
\text { AAAs }\end{array}$ & $\begin{array}{c}\text { CDOs } \\
\text { (resi. subs) }\end{array}$ & $\begin{array}{c}\text { Residential } \\
\text { subs }\end{array}$ & $\begin{array}{c}\text { Total } \\
\text { Exposure }\end{array}$ \\
\hline US banks/Thrifts & 2,020 & 869 & 852 & 383 & 90 & 0 & 4,212 \\
GSEs/FHLB & 444 & 0 & 741 & 308 & 0 & 0 & 1,493 \\
Broker/Dealers & 0 & 0 & 49 & 100 & 130 & 24 & 303 \\
REITs & 0 & 0 & 82 & 10 & 0 & 0 & 92 \\
Hedge Funds & 0 & 0 & 50 & 51 & 0 & 24 & 126 \\
Money Managers & 0 & 0 & 494 & 225 & 0 & 24 & 743 \\
Insurance Cos. & 0 & 0 & 856 & 125 & 65 & 24 & 1,070 \\
Overseas & 0 & 0 & 689 & 413 & 45 & 24 & 1,172 \\
Financial Guarantors & 0 & 62 & 0 & 0 & 100 & 0 & 162 \\
Others & 461 & 185 & 550 & 21 & 45 & 0 & 1,262 \\
\hline Total & 2,925 & 1,116 & 4,362 & 1,636 & 476 & 121 & 10,680 \\
\hline \hline
\end{tabular}

Table 5. Exposure of Financial Institutions to Housing Risk on the Eve of the Crisis. This table shows that despite their ostensible use of the originate-to-distribute model, investment banks retained large amounts of subprime risk on their balance sheets. In particular, broker/dealers held $\$ 130$ billion in collateralized debt obligations (CDOs) that were ultimately backed by residential mortgages. These investments would suffer massive losses when the subprime bonds backing them defaulted en masse during the financial crisis.

Source: Figure 4 from "Residential Credit Losses-Going into Extra Innings?" Lehman Brothers U.S. Securitized Products, April 11, 2008 and reprinted in Acharya and Richardson (2009). 